\title{
ICHTML 2021 - A journal of the pandemic year
}

\author{
Vita Hamaniuk $^{1, *}$, Serhiy Semerikov ${ }^{1, * *}$, and Yaroslav Shramko ${ }^{1, * * *}$ \\ ${ }^{1}$ Kryvyi Rih State Pedagogical University, 54 Gagarin Ave., Kryvyi Rih, 50086, Ukraine
}

\begin{abstract}
This is an introductory text to a collection of papers from the ICHTML 2021: Second International Conference on History, Theory and Methodology of Learning, which held in Kryvyi Rih State Pedagogical University, Kryvyi Rih, Ukraine, on the May 12-14, 2021. It consists of short introduction, conference review and some observations about the event and its future.
\end{abstract}

\section{ICHTML 2021: At a glance}

The International Conference on History, Theory and Methodology of Learning (ICHTML, https://ichtml.org) is a regular peer-reviewed international conference [1], which covers interdisciplinary research on education, learning and training, and applications of theories and philosophies used in the sciences of learning and adjacent sciences.

The ICHTML occupies contributions in all aspects of epistemology, psychology of learning, learning theories, learning technologies and tools, paradigms and models and related fields of interest with a emphasis on human and machine learning. The main problematic field of the conference is the current and future issues of modern pedagogical science: psychological and pedagogical, philosophical, socio-cultural aspects of education, learning and training, modern theories, technologies and teaching aids, the emergence of which is determined by globalization, integration processes, social transformations, humanitarian and scientific and technological development. There is urgent general need for principled changes in postclassic education elicited by current theories, models, tools, services, networks and communications.

This volume contains the papers presented at ICHTML 2021: Second International Conference on History, Theory and Methodology of Learning held on the May 12-14, 2021 in Kryvyi Rih, Ukraine.

There were 61 submissions. Each submission was reviewed by at least 3 , and on the average 3.2 , program committee members. The committee decided to accept 38 papers.

ICHTML 2021 papers are grouped into 3 tracks:

Track 1: History of Learning and Education

- Evolution of Education, Learning and Training (papers [2], [3], [4], [5])

- Personalia (paper [6])

\footnotetext{
*e-mail: vitana65@gmail.com

**e-mail: semerikov@gmail.com

***e-mail: shramko@rocketmail.com
}

- World Trends in Learning, Training and Education Development (papers [7], [8])

Track 2: Learning Theories

- Analytical Psychology and Learning (papers [9], [10])

- Assessment in Learning (paper [11])

- Development and Learning (papers [12], [13], [14], [15], [16], [17], [18], [19])

- Discourse and the Production of Knowledge (papers [13], [20], [21])

- Philosophy of Learning (papers [22], [23])

- Psychology of Learning (papers [9], [24], [25])

Track 3: Learning Methodology

- Learning Technology (papers [3], [26], [27], [28], [29], [30], [31], [32], [22], [33], [34], [35], [36], [37])

- Sociology of Education (papers [38], [39])

\section{ICHTML 2021: Venue}

Kryvyi Rih State Pedagogical University (https://kdpu. edu.ua/en) is one of the leading institutions of higher education in the education system of Ukraine. The University has more then 90 -year experience in training generations of specialists for the state and public needs (figure 1).

Today the University is a center of education and science in Kryvyi Rih, as well as a center of culture because, in addition to Pedagogical specialties at all three educational levels, Kryvyi Rih State University trains specialists in tourism, ecology, it also prepares philologists, translators, historians and jurists, designers and choreographers for educational institutions of the city and region.

Kryvyi Rih State Pedagogical University has a long history, ancient traditions and it cherishes them up to this day. It was founded in 1930 as an institute of vocational education, but over time the number of specialties, which 


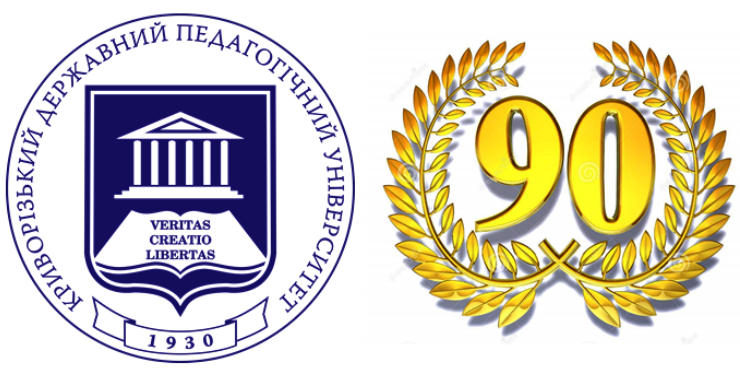

Figure 1. Kryvyi Rih State Pedagogical University logo

applicants studied at, as well as the status of the institution increased: Kryvyi Rih State Pedagogical Institute, and since 2001 - Kryvyi Rih State Pedagogical University. In 2011-2015 KSPU functioned as a structural unit of the Kryvyi Rih National University, and since 2016 as Kryvyi Rih State Pedagogical University. Currently, the university trains specialists in 30 specialties of the first (bachelor's) level, in 19 specialties of the second (master's) level and in 14 specialties of the third (educational and scientific) level.

The university has 8 faculties: Ukrainian Philology, Foreign Languages, Geography, Tourism and History, Preschool and Technological Education, Physics and Mathematics, Science, Psychology and Pedagogy and the Faculty of Arts, which includes Music and Pedagogy, Art and Graphic departments. The university conducts research in four areas: Mathematical and Natural Sciences (Primarily Physics and Ecology), Social Sciences (Pedagogy, Sociology, Psychology), Humanities (Philology, Philosophy, History) and Biology. The educational process is provided by 29 doctors of sciences, professors, 219 candidates of sciences, associate professors.

The university has international contacts with more than 30 higher education institutions and research institutions in foreign countries. Researchers and applicants participate in international projects and European academic mobility programs.

Despite the pandemic and economic difficulties in the country, the university is dynamically developing and advancing in the domestic rankings among higher education institutions. Thus, Kryvyi Rih State Pedagogical University maintained and, according to some indicators, improved its position in 2020. KSPU is on 36th place out of 190 universities according to the rank of Scopus (for comparison: $2019-91)$, in the TOP-200 on 75th (2019157), and in the consolidated ranking - 101-105 (2019148-151), which we shared with other universities, from 24. In 2019 KSPU entered the top ten pedagogical universities of Ukraine, and in 2020 consolidated its position and now it takes the 8th position in the consolidated ranking.

In $2018 \mathrm{KSPU}$ data were added to another rating, namely: U-Multirank 2018/19. In 2020 Kryvyi Rih State Pedagogical University improved its indicators and rose from 89th place to 71 out of 176 universities.

\section{ICHTML 2021: Program committee}



Dr. George Abuselidze, Professor of Economics and Business, Department of Finance, Banking and Insurance, Batumi Shota Rustaveli State University, Batumi, Georgia George Abuselidze, from the Batumi Shota Rustaveli State University (in 2001) and Ivane Javakhishvili Tbilisi State University, Georgia, in 2005, and a Doctor of Economics Sciences degree (Dr. habil.) from the National Academy of Sciences of Georgia, in 2005. Since 2002, he has been working in the Finance and Banking at the Ivane Javakhishvili Tbilisi State University, since 2006 Batumi Shota Rustaveli State University where he is currently Head department of Finance, Banking and Insurance. His research interests include Economics, Econometrics, Finance and Social Sciences (miscellaneous). He has published a number of papers in international journals and volumes in book series, is a member of editorial or/and review boards of Oeconomia Copernicana, Journal of Financial Economic Policy, International Journal of Economics and Finance, journal of Science and studies of accounting and finance: problems and perspectives, Management Studies and etc. He also played instrumental role in different prestigious internal collaborative research project with USA, Canada, Lithuania, Poland, Ukraine, Turkey and etc.

WWW: https://orcid.org/0000-0002-5834-1233

e-mail: george.abuselidze@bsu.edu.ge

Dt. Svitlana Amelina, Doctor of Education, Professor, Head of the Department of Foreign Philology and Translation, National University of Life and Environmental Sciences of Ukraine, Kyiv, Ukraine

Svitlana Amelina, born in 1961, received a Candidate of Philological Sciences degree (Dr. phil.) in 1994 and a Doctor of Pedagogical Sciences degree (Dr. habil.) in 2009. She studied at the Humboldt-Universität zu Berlin, trained at the largest universities in Germany and France. Since 2012, she has been working at the National University of Life and Environmental Sciences of Ukraine. Her research interests include theory and methodology of professional education; pedagogy of higher school; 




methods of teaching foreign languages and translation; syntax, semantics and pragmatics of the Germanic languages. She participated in numerous scientific-theoretical and scientific-practical conferences. She was a member of numerous scientific-theoretical and scientific-practical conferences. She is the author of many scientific publications, including monographs, articles, and reports.

e-mail: svetlanaamelina@ukr.net



Dr. Vira Andriievska, Associate Professor, Department of Informatics, H.S. Skovoroda Kharkiv National Pedagogical University, Kharkiv, Ukraine
Vira Andriievska, born in 1980, received a Candidate of Pedagogical Sciences degree (2009) and a Doctor of Pedagogical Sciences degree (2019) from the H.S. Skovoroda Kharkiv National Pedagogical University. Research coordinator of the Faculty of Physics and Mathematics (2020). Since 2004, she has been working in the field of primary education at the H.S. Skovoroda Kharkiv National Pedagogical University. Her research interests include training future primary school teachers to use ICT in their professional activities. Present research interests include the project-based learning, STEM education and social media in education. She has published a number of papers in international journals.

WWW: http://kafinfo.org.ua

e-mail: andvera80@gmail.com

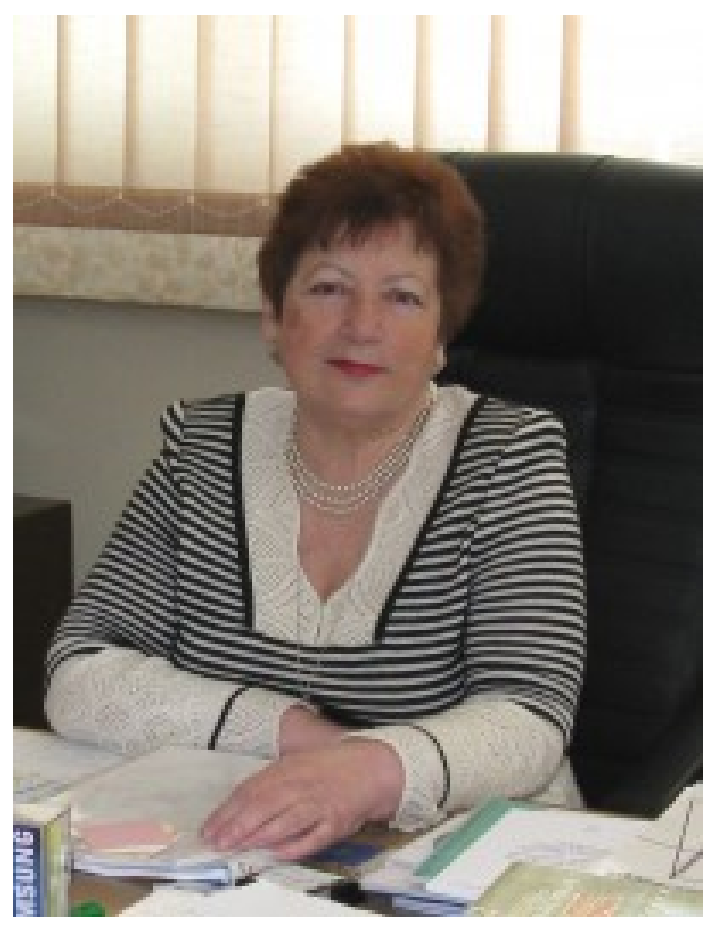

Dr. Liudmyla Bilousova, Full Professor, Independent researcher, Kharkiv, Ukraine.

Liudmyla Bilousova got a M.A. in Radio-physics from Kharkiv State University, USSR (1959), and PhD in physical-mathematical science from Kharkiv State University, USSR (1970). Liudmyla Bilousova headed Computer Science Department at G.S. Skovoroda Kharkiv National Pedagogical University for 27 years (1991-2018). She is a founder and a head of her scientific school on the problems of development of Informatics education and the implementation of innovative technologies in educational process. In the framework of the school a series of $\mathrm{PhD}$ and doctoral research has been completed. Dr. Liudmyla Bilousova is a scientific supervisor of $23 \mathrm{PhD}$ theses. She is an author of about 400 scientific and methodical works including 5 collective monograph and 64 tutorials. Liudmyla Bilousova is a PC member of International Conference ICTERI-2019, International Workshop CTE, and ICon-MaSTEd 2020. 
WWW:

bilousova-lyudmyla-ivanivna e-mail: lib215@gmail.com



Dr. Olga Bondarenko, Candidate of Pedagogical Sciences, Associate Professor, Department of Economic and Social Geography and Methods of Teaching, Kryvyi Rih, Kryvyi Rih State Pedagogical University Kryvyi Rih, Ukraine

Olga Bondarenko, born in 1979, in 2001 graduated with honors from the geographical faculty of Krivoy Rog State Pedagogical University, majoring in "Pedagogy and Methodology of Secondary Education. Geography and Biology", acquired Bachelor Degree. In 2002 she received a Master Degree with honors in the major "Pedagogy and Methodology of Secondary Education. Geography», qualified as a teacher of geography. In 2009, she successfully defended her $\mathrm{PhD}$ thesis at the Republican Higher Educational Institution "Crimean Humanities University" (Yalta) and received a $\mathrm{PhD}$ in Pedagogical Sciences. Since 2005 he has been working at Kryvyi Rih State Pedagogical University. Author of a number of scientific publications on vocational education, training of future teachers for pedagogical activity. Her research interests include teacher training, the use of ICTs and GIS technologies in the educational process. html

WWW: https://kdpu.edu.ua/personal/ovbondarenko.

e-mail: bondarenko.olga@kdpu.edu.ua

Ing. Helena Fidlerová, Ph.D., a senior researcher at the Slovak University of Technology in Bratislava, Faculty of Materials Science and Technology in Trnava, Institute of Industrial Engineering and Management, Slovakia
Ing. Helena Fidlerová, Ph.D. received her Ph.D. degree in the field of Industrial Management in 2006. Her research aims at issues of education, STEM education, digital competences, Industry 4.0, Education 4.0, industrial engineering, sustainable competences, and the application of statistical methods. Since her study has extensive experience in domestic research projects under Slovak Ministry of Education VEGA, KEGA), and international projects e.g. ALTECS - Knowledge exchange in the framework of alternative economic systems for the promotion of sustainable regional development; International Visegrad Fund No. -21810100: Academic Research Consortium integrating databases, robotics, and language technologies. He is a project leader for Slovakia in Erasmus + KA2 project: Knowledge Alliance for Business Opportunity Recognition in SDGs. She is a member of the Slovak Statistical and Demographic Society (SDSS), a member of the International Association of Engineers (IAENG and member of the editorial board of Acta logistica.

WWW: https://orcid.org/0000-0002-3426-5803

e-mail: helena.fidlerova@stuba.sk

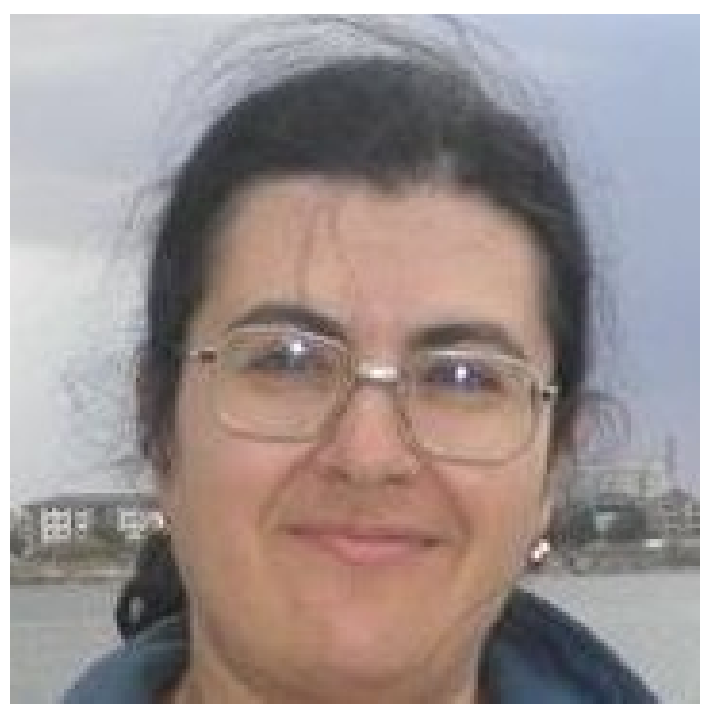

Dr. Irina Georgescu, Lecturer of Computational Intelligence, Department of Informatics and Economic Cybernetics, Bucharest University of Economics, Bucharest, Romania

Irina GEORGESCU holds a $\mathrm{PhD}$ in Economics from Turku Centre for Computer Science, Turku, Finland. Currently she is a lecturer at the Department of Economic Informatics and Cybernetics, Bucharest Academy of Economic Studies. Her research interests lie in the areas of fuzzy economics, computational intelligence and econometrics. She is the author of about 40 journal papers and 2 books published in Springer Verlag.

e-mail: irina.georgescu@csie.ase.ro

Dr. Olena Glazunova, Professor of ICT in Education, Department of Information Technologies, National University of Life and Environmental Sciences of Ukraine

Olena Glazunova, received a Candidate of Pedagogical Sciences degree (Dr. phil.) in 2003, and a Doctor of 




Pedagogical Sciences degree (Dr. habil.) from the Institute of Informational Technologies and Tools in Education NAPS of Ukraine in 2015. Since 2003, she has been working in the field of design and development of cloudbased scientific-educational environment of the university, use of technologies of inquiry-based and project-based activities and implementation of teamwork approaches in ITstudents learning, transfer and modification of educational methods to specialized teaching of research masters' programs and courses of e-learning management.

WWW: https://nubip.edu.ua/IT.NUBIP

e-mail: o-glazunova@nubip.edu.ua



Prof. Dr. Yüksel Göktaş, Ataturk University, Turkey
WWW: https://yukselgoktas.com/

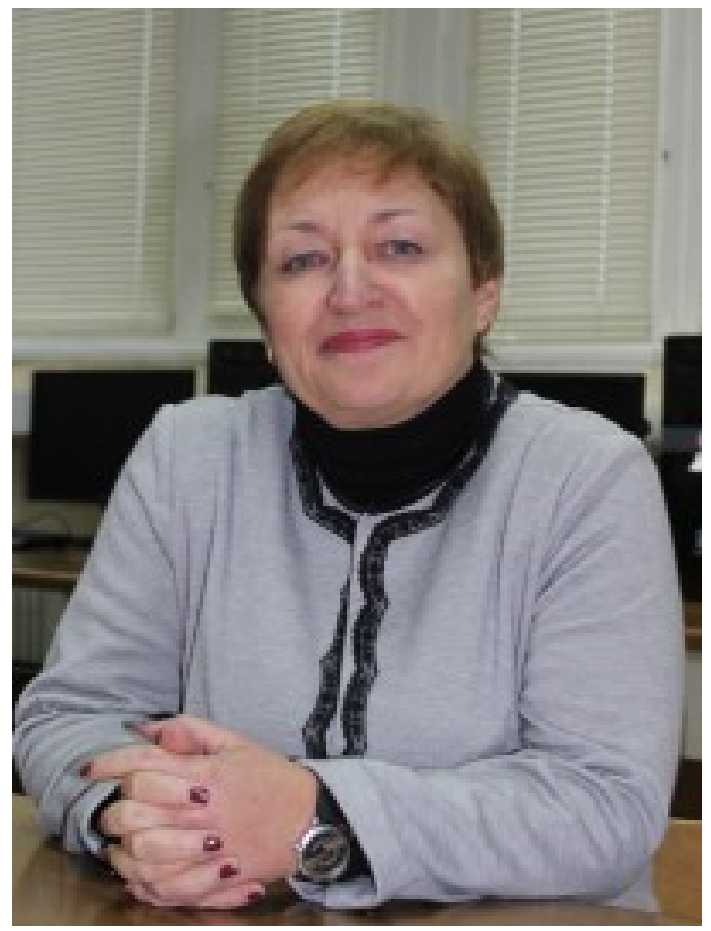

Dr. Liudmyla Gryzun, Full Professor of Information System Department at Simon Kuznets Kharkiv National University of Economics, Ukraine.

Liudmyla Gryzun earned a M.A. in Applied Mathematics from the Kharkiv State University, USSR (1986); $\mathrm{PhD}$ and Second Doctoral Degree in Pedagogical science from G.S. Skovoroda Kharkiv National Pedagogical University (Ukraine). The sphere of her research is focused on the curriculum and educational content design in higher education, the process of curriculum disciplines structuring, based on scientific knowledge integration; AI application to pedagogical problems solution; IT tools for inquiry-based and holistic learning etc. She is an author of more than 120 scientific and methodical works including 1 monograph, 2 collective monographs, and 6 tutorials. Liudmyla Gryzun has delivered a number of Keynote presentations at the International conferences: 2018 ICTEL (Rome, Italy), 2018 ICRTEL (Barcelona, Spain), 2019 ICSTR (Rome, Italy), 2020 ICSTR (Berlin, Germany; Paris, France; London, UK) and others. She is also a reviewer of the foreign journals (Universal Journal of Educational Research (USA); Athens Journal of Education, IJIRES (International Journal of Innovation and Research in Educational Sciences)). Liudmyla Gryzun is a PC member of International Workshop CTE and ICon-MaSTEd 2020.

WWW: node/295, http://www.is.ksue.edu.ua/?q= https://www.linkedin.com/in/ liudmyla-gryzun-68769280/, https://www.researchgate. net/profile/Liudmyla_Gryzun

e-mail: Lgr2007@ukr.net

Dr. Yasemin Gülbahar, Professor of Computer Education and Instructional Technologies (CEIT), Ankara University, Ankara, Turkey 


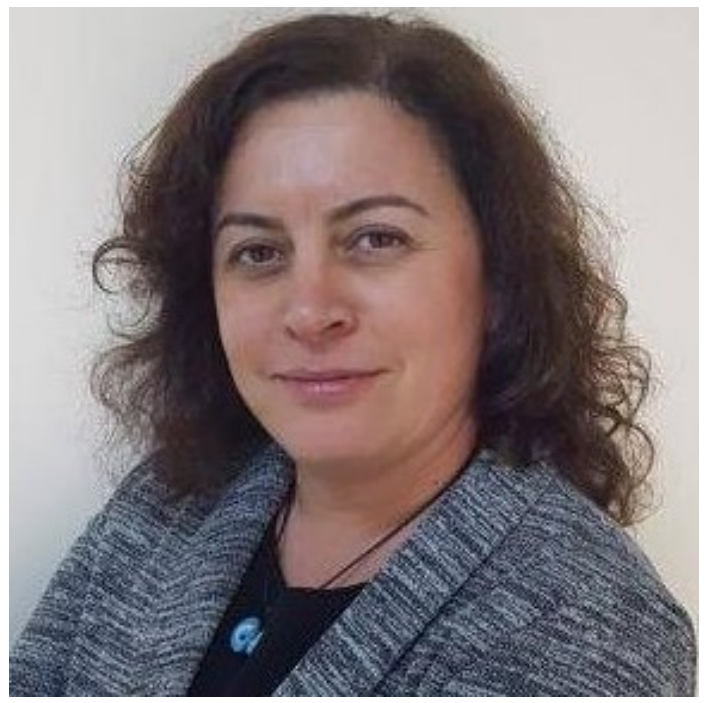

Dr. Gülbahar has got her BS degree from Department of Mathematics of Science Faculty at Middle East Technical University (METU) in 1992. Same year she started working as a programmer at METU Computer Center. Then, in 1998, she became a research assistant to the Department of CEIT in the Faculty of Education, METU while studying her MS degree at the same department. She earned his MS degree in the field of Science Education at METU Graduate School of Science in 1999 and she received her PhD in Department of CEIT from Graduate School of Sciences in 2002. After, she worked for Başkent University Faculty of Education Department of CEIT for about 9 years. Since 2011 she is a faculty member of Ankara University. Dr. Gülbahar has got her Associate Professor degree in 2009 and full Professor Degree in 2014.

Yasemin Gülbahar has lectured on many topics such as programming languages, problem solving and algorithms, instructional technologies, instructional design, material design and development, distance learning, web design, measurement and evaluation, research methods, teaching methods, software development, technology integration and planning both in undergraduate and graduate level. She has also many national and international publications as books, book chapters, journal articles and proceeding papers.

WWW: http://cv.ankara.edu.tr/gulbahar@ankara.edu. $\operatorname{tr}$

e-mail: gulbahar@ankara.edu.tr

Vita Hamaniuk, Professor of German, Literature and Didactics, Department of German, Literature and Didactics, Kryvyi Rih State Pedadogical University, Kryvyi Rih, Ukraine

Vita Hamaniuk, born in 1965, 1995 received a Candidate of Pedagogical Sciences degree (Dr. ped.) from the Kharkiv State Pedagogical H. Scovoroda University, in 2013 - a Doctor of Pedagogical Sciences degree (Dr. habil.) from the East-Ukrainian National Volodymyr Dahl University. In 2001 she received his habilitation as the Docent (Assoc. Prof.) at the Department of Foreign Lan-



guages of Kryvyi Rih State Pedagogical University. In 2015 she received his habilitation as the Professor (Full Prof.) at the Department of German, Literature and Didactics of Kryvyi Rih State Pedagogical University. From September 1995 until now Vita Hamaniuk worked as a head of Department of Foreign Languages, as an Associate Professor, Head of Department, Full Professor of Department of German, Literature and Didactics. From April 2017, she works as vice-rector for research at Kryvyi Rih State Pedagogical University. Her research interests include foreign languages teaching and learning, didactics of multilingualism, e-learning, blended learning, comparative researches in Education. She has published a number of papers in Ukrainian and international journals, actively participates in international conferences and projects.

WWW: https://kdpu.edu.ua/personal/vagamanuk.html e-mail: vitana65@gmail.com




Dr. Anna Iatsyshyn, Senior Researcher, Department of Civil Protection and Innovation, State Institution "The Institute of Environmental Geochemistry of National Academy of Sciences of Ukraine”, Kyiv, Ukraine.

Anna Iatsyshyn, born in 1984, received a Candidate of Pedagogic Sciences degree from the Ivan Ziaziun Institute of Pedagogical and Adult Education of the National Academy of Educational Sciences of Ukraine, in 2010. A. Iatsyshyn is actively engaged in scientific activities in such areas as ICT in education and research, digitalization of education, adult education, electronic libraries, electronic social networks, training of future $\mathrm{PhD}$, scientometrics. She has published a number of papers in international journals and monographs, is an associate member of editorial board of journal "Information Technologies and Learning Tools" and a member of editorial board of journal "Education and Development of Gifted Personality".

WWW: http://www.nas.gov.ua/EN/PersonalSite/ Statuses/Pages/default.aspx?PersonID=0000030359

e-mail: anna13.00.10@gmail.com

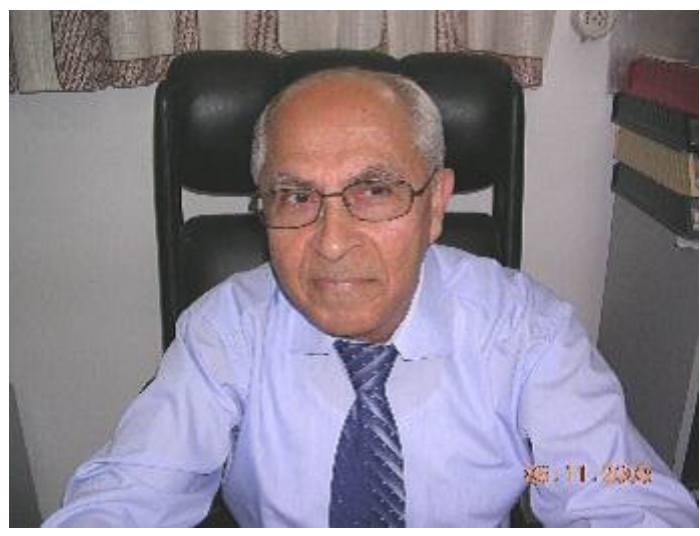

Dr. Arnold Kiv, Ben-Gurion University of the Negev, Israel

Arnold Kiv received the D. Sc. (Dr. Hab.) degree in solid state physics from Tartu Institute of Physics, Tartu, Estonia, in 1978. From 1964 to 1982, he was a Senior Researcher and a Head of the Laboratory of Radiation Effects, Institute of Nuclear Physics, Academy of Sciences, Tashkent, Uzbekistan. From 1983 to 1998, he was a Head of the Department of Theoretical Physics, South-Ukrainian National Pedagogical University, Odessa, Ukraine. In 1997, he was an Invited Professor, Western Ontario University, Canada. From 1999 to the present, he is a Professor-Researcher in the Department of Materials Engineering, Ben-Gurion University of the Negev, Israel. In 1996 and 2011 he was co-Director of NATO Advanced research Workshops and an Editor of two NATO Series books. He has about 200 publications, three monographs and three Invention Certificates in the field of radiation effects in solid state electronics. His research interests include mechanisms of formation of radiation defects in solids, interaction of fast particles with materials, radiation methods in microelectronics, including computer simulation, analytical calculations and experimental studies.

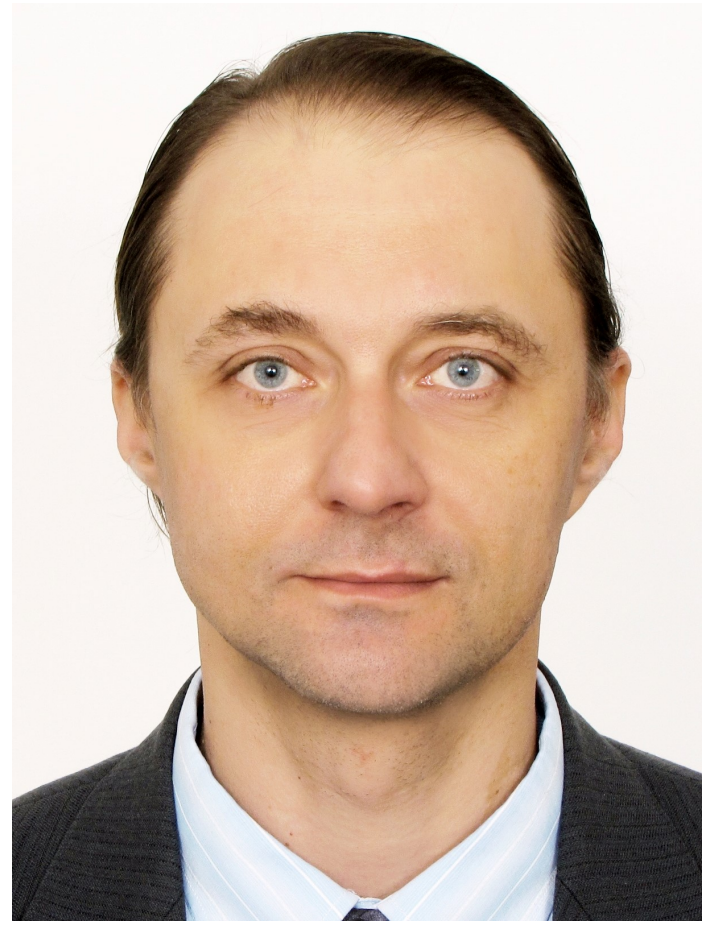

Dr. Oleksandr Kolgatin, Professor of Informatics, Department of Information Systems, Simon Kuznets Kharkiv National University of Economics, Kharkiv, Ukraine

Oleksandr Kolgatin, born in 1966, received a Candidate of Technical Sciences degree (Dr. phil.) from the Institute for Low Temperature Physics and Engineering of the National Academy of Sciences of Ukraine, in 1995, the field of scientific interests was computational modeling of the heat and mass transfer processes. Since 1990, he worked in the field of teaching informatics and using information technologies in education and received a Doctor of Pedagogical Sciences degree (Dr. habil.) from the Institute of Information technologies and Learning Tools of the National Academy of Pedagogical Sciences of Ukraine, in 2011. His research interests include computational modeling, pedagogical diagnostics, information systems and technologies in education. He has published a number of papers in international journals and volumes in book series, is a member of editorial boards of Journal of Information Technologies in Education and associate editor of Information Technologies and Learning Tools.

WWW: http://www.is.hneu.edu.ua/?q=node/294

e-mail: kolgatin@ukr.net

Prof. Zhanna Koloiz, Doctor of Philological Sciences, Full Professor, Head of the Ukrainian Language Department, Kryvyi Rih State Pedagogical University, the Editor-in-chief of the collection of scientific works "Philological Studies: Scientific Bulletin of Kryvyi Rih State Pedagogical University", the author of more than 200 scientific papers.

In 1991 she graduated the Ivan Franko National University of Lviv. Since then she has been working at Kryvyi 


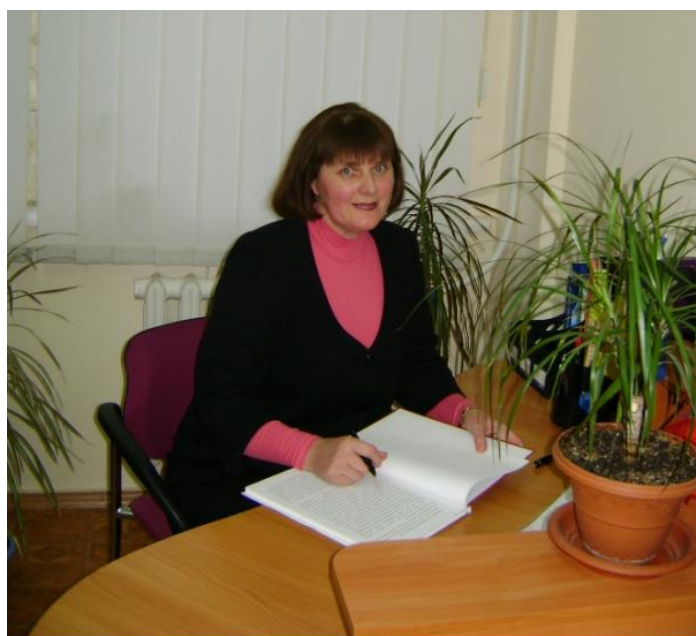

Rih State Pedagogical University. She received the Candidate of Philological Sciences degree in specialty 10.02.01 - Ukrainian language, in the Oles Honchar Dnipropetrovsk National University in 1996. She received the academic title of the Associate Professor in 2000. In 2007 she completed her doctoral studies at the Department of the Ukrainian Language of V.N. Karazin Kharkiv National University. She defended her doctoral dissertation on September 25, 2007 in the Institute of the Ukrainian Language of the National Academy of Sciences of Ukraine. In 2010 she received her academic title of Full Professor. Her research interests include neology and neography, occasional derivation, phraseology, paremiology, ethnolinguistics, academic writing, academic style, academic culture.

WWW: https://kdpu.edu.ua/personal/zhvkoloiz.html

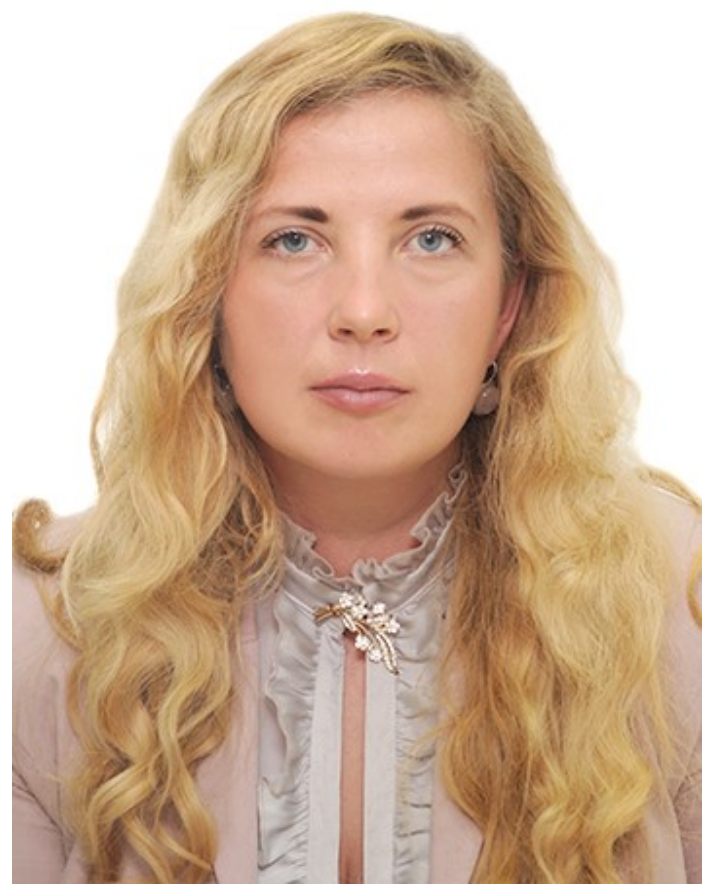

Dr. Svitlana Kovpik, Doctor of Philological Sciences, Professor of the Department of the Ukrainian and
World Literatures, Kryvyi Rih State Pedagogical University, Kryvyi Rih, Ukraine.

Svitlana Kovpik, born in 1977, received the Candidate of Philological Sciences degree (Dr.phil.) from Kherson State University in 2005, and Doctor of Philological Sciences degree (Dr. habil.) from Taras Shevchenko National University of Kyiv, in 2011. Since 2001, she has been working in the field of Philology at Kryvyi Rih State Pedadogical University, where she is currently a Professor. Her research interests include poetics of fiction. She has published a number of articles in international journals and she is the editor-in-chief of the scientific journal "Literatures of the World: Poetics, Mentality and Spirituality". e-mail: kovpiks@ukr.net

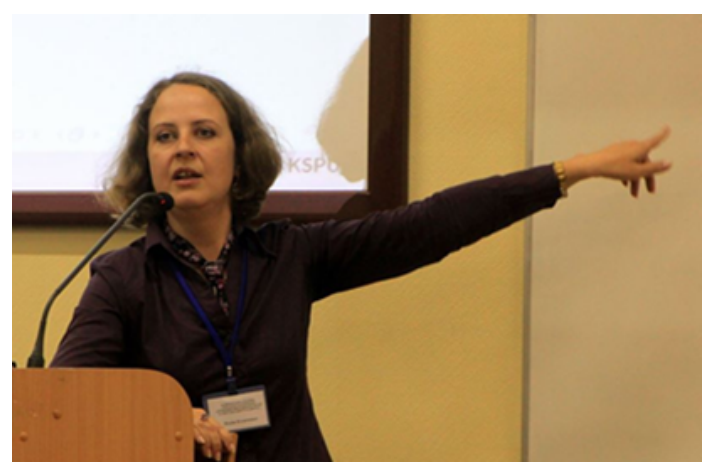

Dr. Nadiia Kozachenko, Kryvyi Rih State Pedagogical University, Ukraine

Dr. Nadiia Kozachenko is former chair of Department of Philosophy at Kryvyi Rih State Pedagogical University. She got $\mathrm{PhD}$ in logic from the Institute of Philosophy of the NAS of Ukraine in 2010. The main directions of Dr. Kozachenko' research is logic and philosophy of information society.

WWW:

kozachenko.html

$$
\text { https://kdpu.edu.ua/personal/n_p_ }
$$

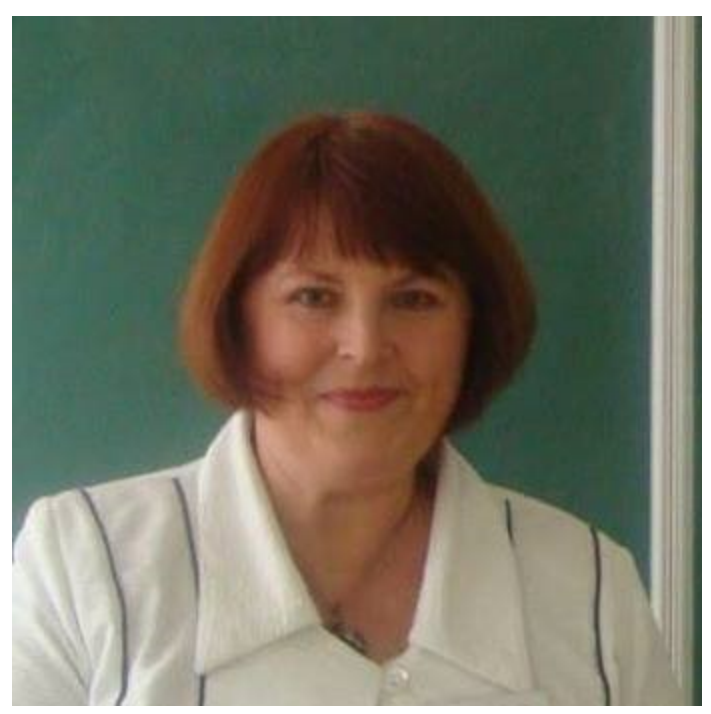

Dr. Tetiana Kramarenko, Associate Professor of the Department of Mathematics and Methods of its Teach- 
ing, Kryvyi Rih State Pedagogical University, Kryvyi Rih, Ukraine

Tetiana Kramarenko received a Candidate of Pedagogical Sciences in speciality 13.00.02 "Theory and methods of studies (Mathematics)" degree (Dr. phil.) from the National Pedagogical Dragomanov University, Kyiv, Ukraine, in 2008. Associate Professor (2011). Scientific interests: Education, Math education, STEM education, ICT in education, Methodology for teaching Mathematics, Probability theory, Mathematical statistics.

WWW: https://kdpu.edu.ua/personal/tkramarenko. html

e-mail: kramarenko.tetyana@kdpu.edu.ua

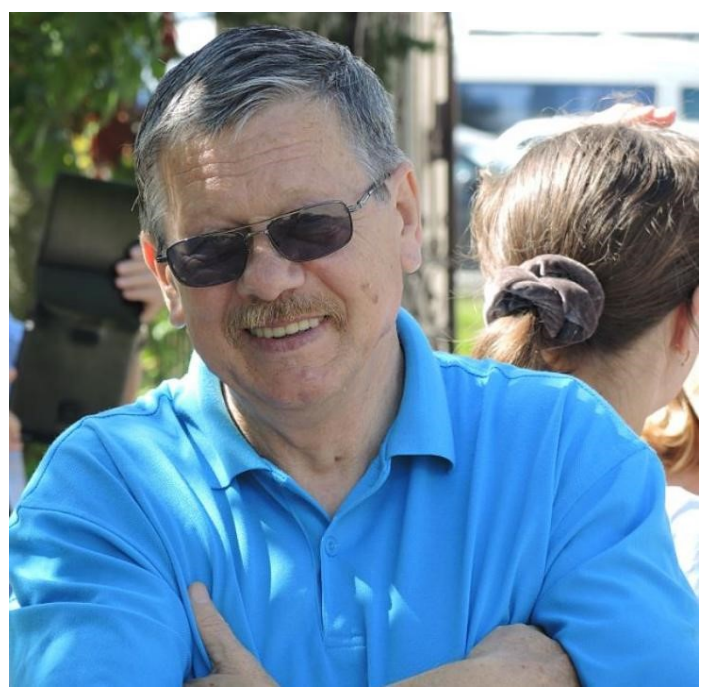

Dr. Volodymyr Kukharenko, Professor of Technical Cryophisics Department, National Technical University «Kharkiv Polytechnic Institute», Kharkiv, Ukraine

Volodymyr Kukharenko, born in 1947, received a Candidate of Technical Sciences degree from Physical Technic Institute of Low Temperature National Academy of Sciences of Ukraine. Since 1976, he has been working in the field of low temperature at the National Technical University "Kharkiv Polytechnic Institute", where he is professor of Technical Cryophisics Department and academician of International Academy of Refrigeration UD. His research interests include distance learning. He has published a number of papers in international journals and six books from creating distance courses, about tutor, blended learning.

WWW: https://dl.khpi.edu.ua

e-mail: kukharenkovn@gmail.com

Dr. Olena Kuzminska, Professor of Department of Information Systems and Technologies, National University of Life and Environmental Sciences of Ukraine, Kyiv, Ukraine

Olena Kuzminska, born in 1970, received a Candidate of Pedagogic Sciences degree (PhD) from the National Pedagogical Dragomanov University (Kyiv) in 2008 and a Doctor of Pedagogic Sciences degree (Dr. habil.) from the State Institution «Taras Shevchenko National University of Luhansk», in 2020. Since 2008, she has been work-

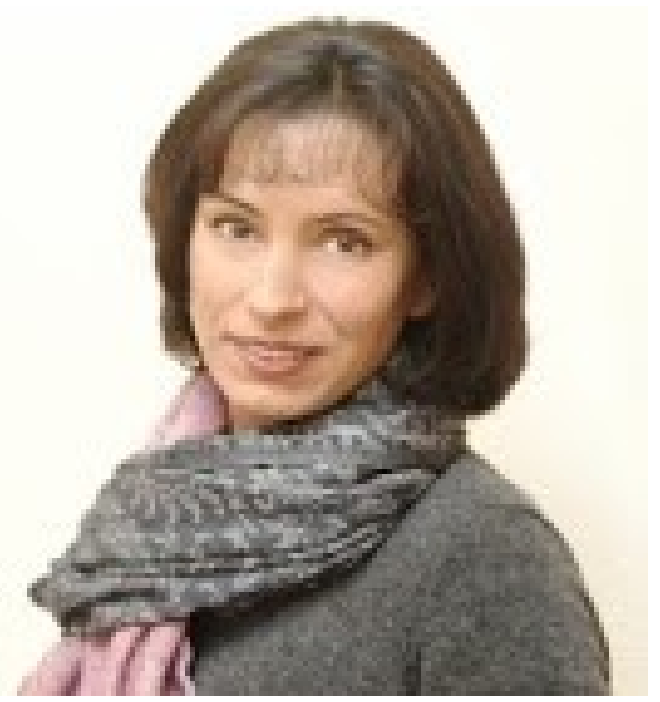

ing at the National University of Life and Environmental Sciences of Ukraine. She research interests include design and integration of scholarly communication tools to digital educational environment of university; use of technologies of inquiry-based and project-based activities and implementation of teamwork approaches as a tool for development of digital competences; transfer and modification of education methods to specialized teaching of research masters' programs and courses of e-learning management and scholarly communication. She has published a number of papers in international journals and volumes in book series, is a member of program committee of International Conferences on ICT in Education and Research.

WWW: https://nubip.edu.ua/node/3900, https://cutt. ly/9thm8Un

e-mail: o.kuzminska@nubip.edu.ua

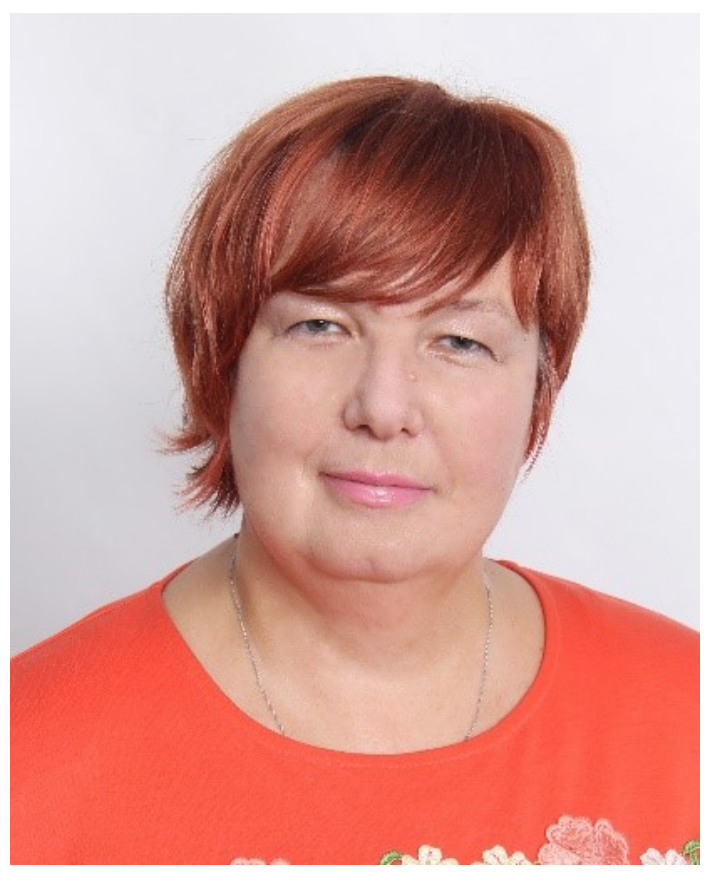

Dr. Olena Lavrentieva, Full Professor, Professor of the Department of Innovative Technologies in Pedagogy, 
Psychology and Social Work, Alfred Nobel University, Dnipro, Ukraine

Olena Lavrentieva, born in 1968, received a Candidate of Pedagogical Sciences degree (Dr. phil.) from the Lesya Ukrainka East European National University, Ukraine, in 2005 by specialty 13.00.09 «Theory of Education», and a Doctor of Pedagogical Sciences degree (Dr. habil.) from the Institute of Teacher Education and Adult Education of the National Academy of Sciences of Ukraine by specialty 13.00.04 «Theory and Methods of Professional Education», in 2015. During 2003-2020 she was working in the Kryvyi Rih State Pedadogical University, now she is working in Alfred Nobel University. Her research interests include didactic and methodology issues of vocational training process. She has published a number of papers in international journals and volumes in book series, is a member of editorial boards of Physical and Mathematical education.

e-mail: lavrenteva.o@duan.edu.ua

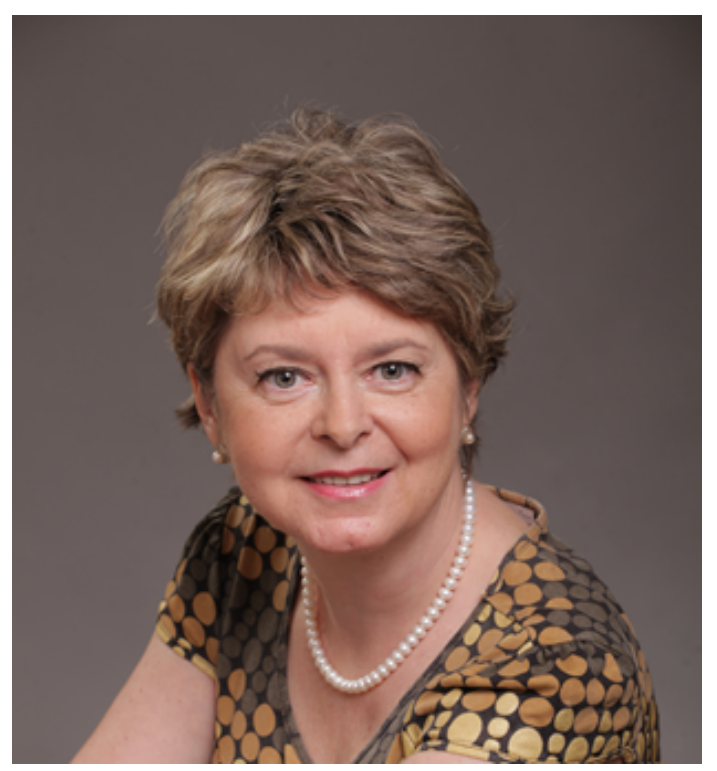

Prof. Olena Lokshyna, Dr. Sc., Head of the Department of Comparative Education, Institute of Pedagogy of the National Academy of Educational Sciences of Ukraine, Kyiv, Ukraine

Olena Lokshyna, born in 1959, received a Candidate of Educational Sciences degree (Dr. phil. in Education) in 1992, and a Doctor of Sciences degree (Dr in Education) from the Institute of Pedagogy of the National Academy of Educational Sciences of Ukraine, in 2011. She has been working in the area of comparative and international education at the Institute of Pedagogy of the National Academy of Educational Sciences of Ukraine since 1990. She received her Professor rank in 2015 and was elected as a Corresponding Member of the National Academy of Educational Sciences of Ukraine in 2019. Her research interests focus on developmental trends and innovations in education in Ukraine and abroad through the lens of comparison, with special interest in reforms, curricula, competences, students' assessment, education quality monitoring, VET, methodology of comparative educa- tion research, education policy analyses. Olena Lokshyna is an author/co-author of about 300 works - monographs and analytical studies, textbooks and course outlines, journal papers and conference abstracts. She teaches courses on comparative and international education for $\mathrm{PhD}$ students at the Institute of Pedagogy and at Borys Grinchenko Kyiv University. She is a member of the editorial boards of the Ukrainian Pedagogical Journal, Education Modern Discourses Journal and Studies in Comparative Education Journal.

WWW: http://undip.org.ua/

e-mail: luve2001@hotmail.com

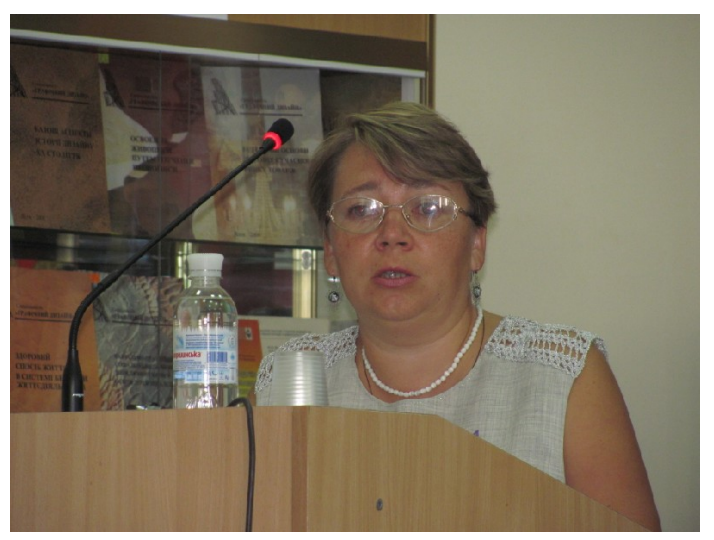

Iryna Lovianova, Doctor of Pedagogical Sciences, Professor of the Department of Mathematics and Methods of its Teaching, Kryvyi Rih State Pedagogical University, Kryvyi Rih, Ukraine.

Irina Lovianova received a Candidate of Pedagogical Sciences degree (Dr. ph.) from the Institute of Pedagogical of the National Academy of Sciences of Ukraine, in 2006, and a Doctor of Philosophical Sciences degree (Dr. habil.) from the The Bohdan Khmelnytsky National University of Cherkasy in 2015. Since 2001, she has been working in the field of didactics of mathematics at the Kryvyi Rih State Pedadogical University. The range of interests is the issues of Education, math education, methodology for teaching mathematics. She has published a number of papers in international journals and collective monographs.

e-mail: lovyanova.iryna@kdpu.edu.ua

Iryna Mintii, Ph. D., associate professor of Computer Science, Department of Computer Science and Applied Mathematics, vice dean of Faculty of Physics and Mathematics, Kryvyi Rih State Pedagogical University, Kryvyi Rih, Ukraine.

Iryna Mintii received a Candidate of Pedagogical Sciences degree (Ph. D.) from the National Pedagogical Dragomanov University, Kyiv, Ukraine, in 2013. Her research interests include ICT in education. She has published a number of papers in international journals.

WWW: https://kdpu.edu.ua/personal/ismintii.html e-mail: irina.mintiy@kdpu.edu.ua 

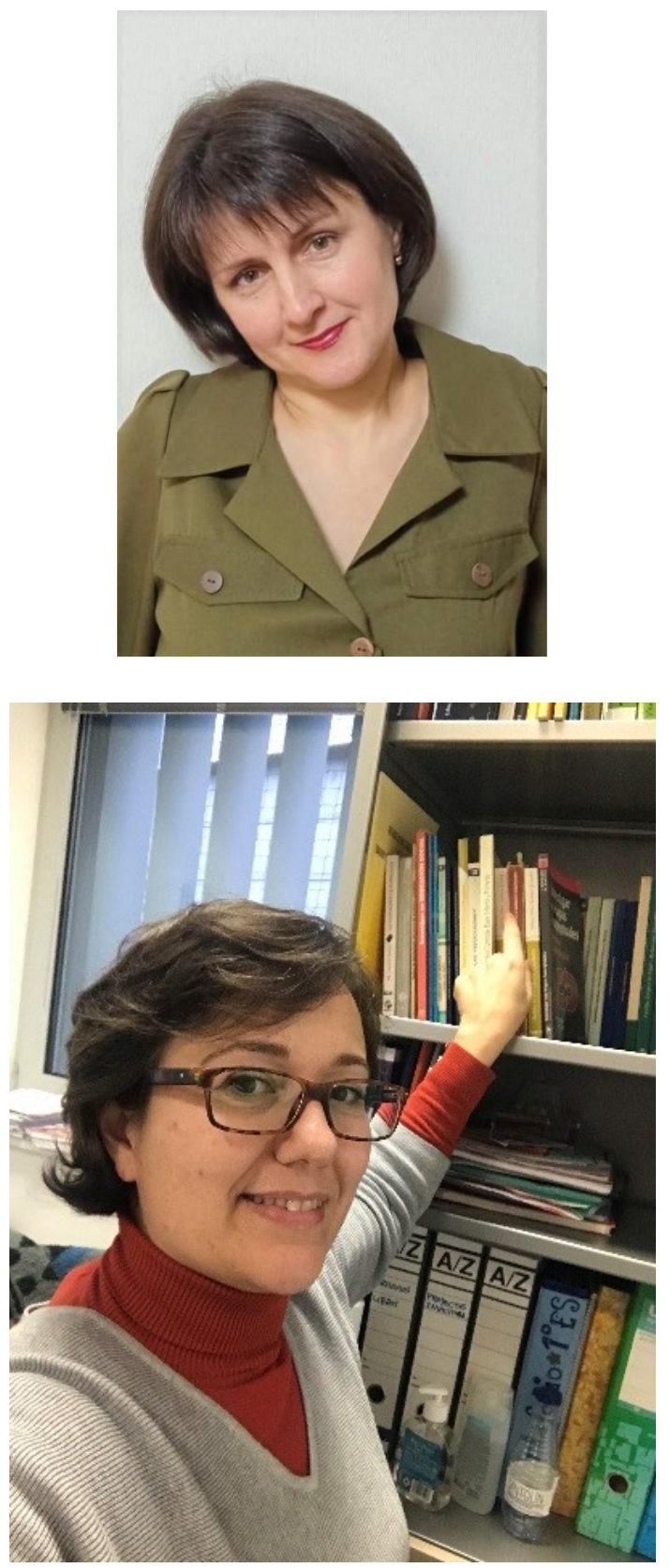

Dra. Pilar Moreno-Crespo, Professor, Department of Research Methods and Diagnosis in Education, Faculty of Education Sciences, University of Seville, Seville, Spain.

Pilar Moreno-Crespo, born in 1978, holds a degree in Philosophy and Educational Sciences, a Ph.D. from the Universidad Pablo de Olavide and was distinguished with the Extraordinary Doctorate Award in 2011. Since 2001, she has been working on adult education, sociocultural animation and educational research methodology. The following lines of research stand out: 1) Adults in socioeducational contexts, 2) Initial teacher training, 3) Educational innovation in higher education. She has published several articles in indexed journals, written several chapters in prestigious publishing houses and has coordinated several books.

WWW: https://orcid.org/0000-0002-6226-0268

e-mail: pmcrespo@us.es

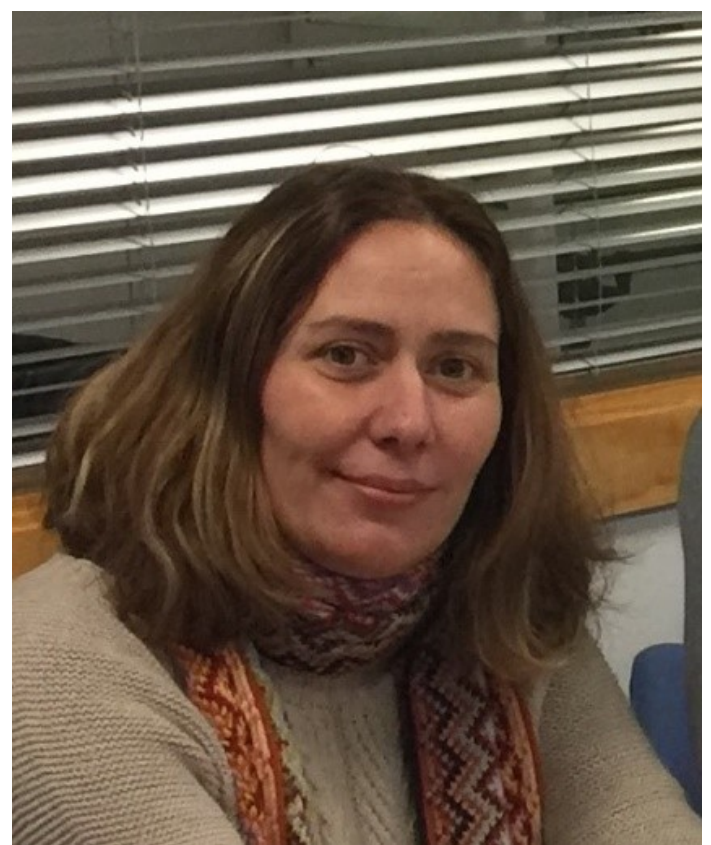

Dr. Olga Moreno-Fernández, Assistant Professor of Didactics of Social Sciences, Department of Didactics of Experimental and Social Sciences, University of Seville, Spain.

Olga Moreno-Fernández, has a degree in Humanities and a Diploma in Primary Education. D. from the Universidad Pablo de Olavide with international mention and extraordinary prize for the work "Environmental education and education for citizenship from a planetary perspective. Study of experiences in Andalucía". She is currently Researcher in charge of the Research Group on Education: Health, Environment and Citizenship (HUM-1027) and editor-in-chief of the journal ESAMEC. Education Journal: Health, Environment and Citizenship. She has participated as a researcher in several research projects, both national and international, related to Citizenship Education. She has published in journals indexed in databases such as SJR or JCR, as well as in publishers indexed in SPI.

WWW: https://investigacion.us.es/sisius/sis_showpub. php?idpers $=18069$

e-mail: omoreno@us.es

Dr. Pavlo Nechypurenko, Associate Professor of Department of Chemistry and Methods of its Teaching, Kryvyi Rih State Pedagogical University, Kryvyi Rih, Ukraine

Pavlo Nechypurenko, born in 1981, received a Magister of Teaching of Chemistry from Kryvyi Rih State Pedagogical University, Ukraine, in 2004, and a Candidate of Pedagogical Sciences degree (Dr. phil.) from the Luhansk Taras Shevchenko National University, Ukraine, in 2017. Since 2004, he has been working in the field of analytical chemistry and method of solving chemical problems at the Kryvyi Rih State Pedagogical University. His research interests include using of ICT on Chemistry education, Analytical Chemistry, Technique of chemical experiment. He has published a number of papers in Ukrainian and inter- 


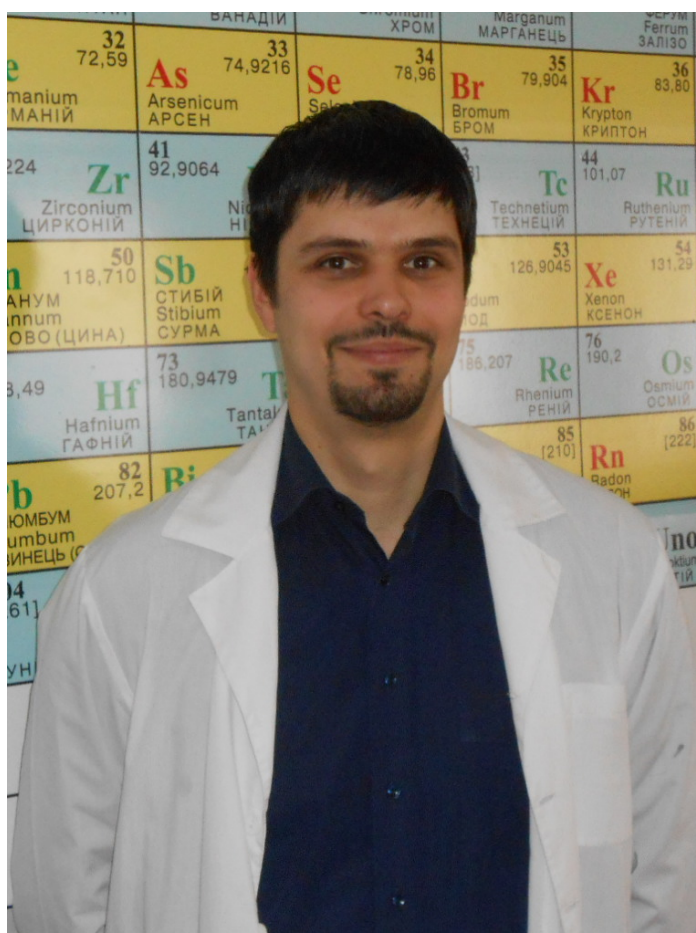

national journals and developed a series of virtual laboratory work to teaching chemistry. edu.ua

e-mail: acinonyxleo@gmail.com,acinonyxleo@kdpu.

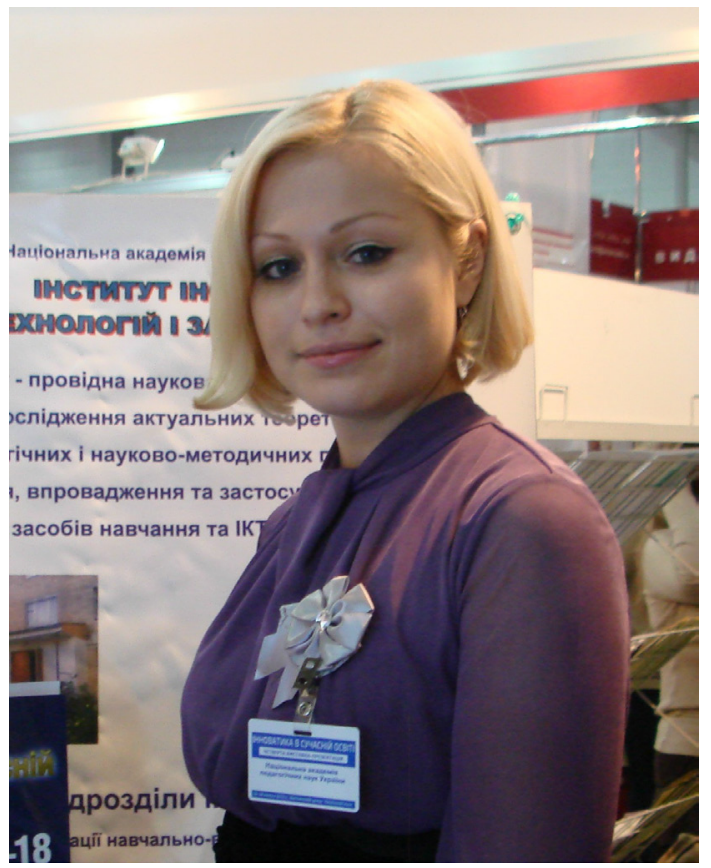

Dr. Yulia Nosenko, Leading Researcher, Department of Cloud-Oriented Systems of Education Informatization, Institute of Information Technologies and Learning Tools of NAES of Ukraine, Kyiv, Ukraine

Yulia Nosenko, born in 1984, received a Candidate of Pedagogical Sciences degree (Dr. phil.) in 2011. In 20102015 worked at Taras Shevchenko National University of Kiev (part time). Since 2010 has been working at the In- stitute of Information Technologies and Learning Tools of National Academy of Educational Sciences of Ukraine, where she is currently leading researcher. Her research interests relates to implementation and use of cloud services in education, formation and development of educators' digital competence, use of ICT as a tool for supporting inclusive learning. She has published over 70 scientific papers, including articles in international journals, is a member of editorial board of peer-reviewed e-journal «Information Technologies and Learning Tools».

WWW: http://iitlt.gov.ua/structure/departments/cloud/ detail.php?ID=48

e-mail: nosenko@iitlt.gov.ua

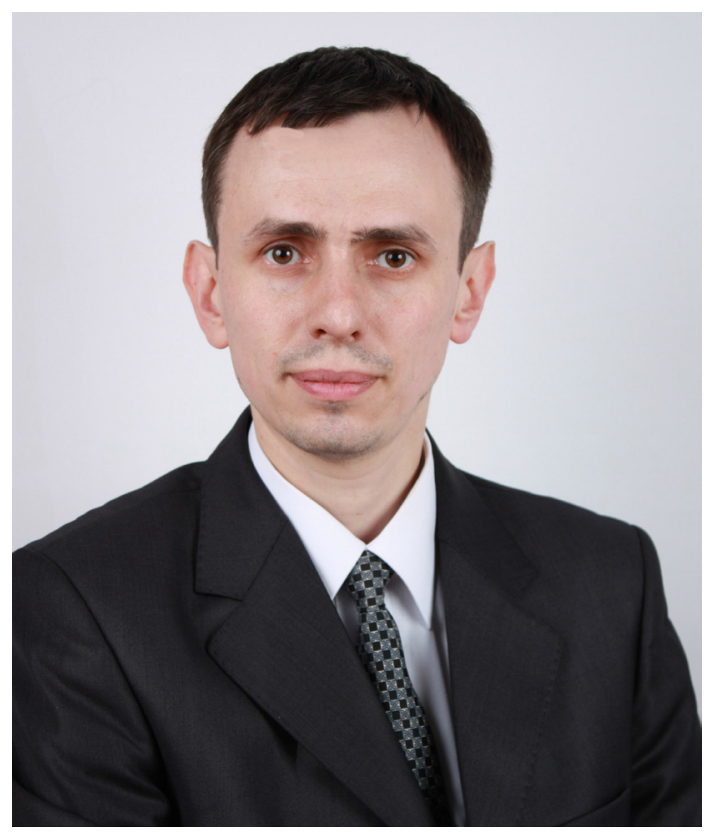

Dr. Vasyl Oleksiuk, $\mathrm{PhD}$ (pedagogical sciences), associate professor of the Department of Computer Science and Teaching Techniques, Ternopil Volodymyr Hnatiuk National Pedagogical University, Ternopil, Ukraine

Vasyl Oleksiuk, born in 1980, received a Candidate of Pedagogical Sciences degree (Dr. phil.) from the National Pedagogical University, Kyiv, Ukraine, in 2007. Since 2003, he has been working Department of Computer Science and Teaching Techniques at Ternopil Volodymyr Hnatiuk National Pedagogical University, where he is currently associate professor. His research interests include computer networks, cloud computing, e-learning, electronic libraries. He has published a number of papers in Ukrainian and international journals, is a member of editorial boards of the journals Information Technologies and Learning Tools (Institute of Information Technologies and Learning Tools of NAES of Ukraine) and The Scientific Issues of Ternopil Volodymyr Hnatiuk National Pedagogical University (Series: pedagogy).

WWW:

http://tnpu.edu.ua/faculty/fizmat/ oleksyuk-vasil-petrovich.php

e-mail: oleksyuk@fizmat.tnpu.edu.ua 


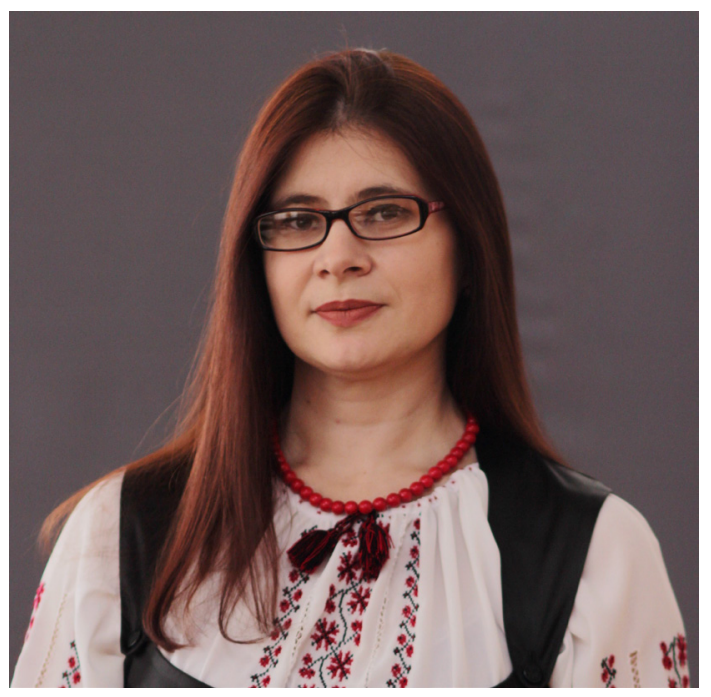

DSc. Kateryna Osadcha, Professor, Department of Computer Science and Cybernetics, Bogdan Khmelnitsky Melitopol state pedagogical university, Melitopol, Ukraine

Kateryna Osadcha, born in 1977, received a Candidate of Pedagogical Sciences (PhD in Education) from the Vinnytsia State Pedagogical University named after Mykhailo Kotsiubynsky, Ukraine, in 2010 and received a Doctor of Pedagogical Sciences (PhD in Education) from the Classic Private University (Zaporizhzhia), Ukraine, in 2020. Since 2011, she has been working as an Associate professor of the Department of Computer Science and Cybernetics at the Bogdan Khmelnitsky Melitopol state pedagogical university. Her research interests include: computer science, network technology, programming, ICT, e-learning, engineering education, educational technology, tutoring. She is author of about a hundred scientific works, including textbooks, monographs, author's certificates. She is a member of editorial boards of "Ukrainian Journal of Educational Studies and Information Technology" (Ukraine), "International Conference on Higher Education Advances" (Spain), "Transactions of Kremenchuk Mykhailo Ostrohradskyi National University" (Ukraine), "Professional Education: Methodology, Theory and Technologies" (Ukraine), «Computing Conference 2021» (United Kingdom).

WWW: http://osadcha.mdpu.org.ua

e-mail: okp@mdpu.org.ua

Dr. Viacheslav Osadchyi, Professor of Department of Computer Science and Cybernetics, Bogdan Khmelnitsky Melitopol state pedagogical university, Melitopol, Ukraine

Viacheslav Osadchyi, born in 1975, received a Candidate of Pedagogical Sciences (PhD in Education) from the Vinnytsia State Pedagogical University named after Mykhailo Kotsiubynsky, Ukraine, in 2006, and a Doctor of Pedagogical Sciences from the Vinnytsia State Pedagogical University named after Mykhailo Kotsiubynsky, Ukraine, in 2013

Since 1999, he has been working in the field of information technology and vocational education at the Bogdan Khmelnitsky Melitopol state pedagogical university. Now - Head of the Department of Computer Science.

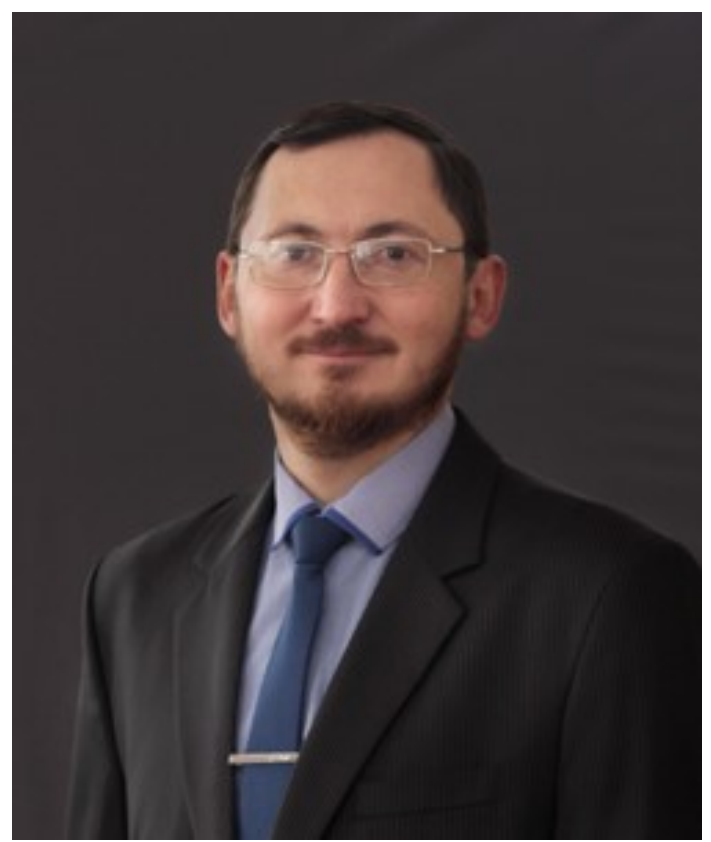

His research interests include: computer science, information networks, ICT, programming, software development, information systems, data science. He has published a number of papers in international journals.

$\mathrm{He}$ is a member of editorial boards of "Ukrainian Journal of Educational Studies and Information Technology" (Ukraine), "Computing Conference (formerly called Science and Information (SAI) Conference)" (UK), Intelligent Systems Conference (IntelliSys) (The Netherlands), "International Conference on Higher Education Advances" (Spain), "Transactions of Kremenchuk Mykhailo Ostrohradskyi National University" (Ukraine), "Information Technologies and Learning Tools" (Ukraine), "Scientific papers of Berdyansk State Pedagogical University Series: Pedagogical sciences" (Ukraine).

WWW: http://osadchyi.mdpu.org.ua/

e-mail: poliform55@gmail.com

Dr. Nataliia Ovcharenko, Professor of Music Art and Pedagogy, Department of Music Education, Vocal and Choir Conducting, Kryvyi Rih State Pedadogical University, Kryvyi Rih, Ukraine

Nataliia Ovcharenko, born in 1965, received a Candidate of Pedadogical Sciences degree (Dr. Phil. (Music Art)) from H.S. Skovoroda Kharkiv National Pedagogical University, USSR, in 1994, and a Doctor of Pedadogical Sciences degree (Dr. habil.) from Borys Grinchenko Kyiv University, Ukraine, in 2016. Since 1990, she has been working in the field of music art and pedagogics at Kryvyi Rih State Pedadogical University. Her research interests include vocal performance, pedagogics and inclusive music education. She has published the papers in international journals and monographs in Ukraine, is a member of National All-Ukrainian Musical Association.

WWW: https://kdpu.edu.ua/personal/naovcharenko. html

e-mail: shvager77@gmail.com 

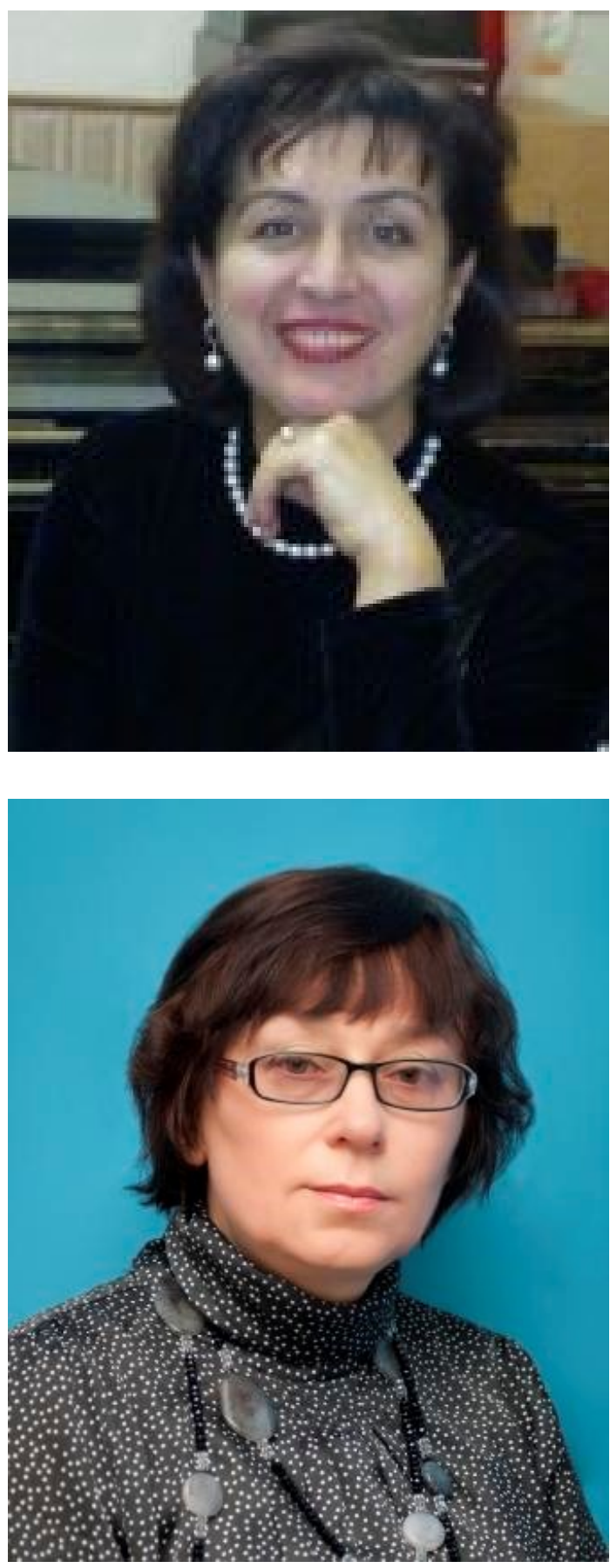

Dr. Liubov Panchenko, Professor at the Department of Sociology, National Technical University of Ukraine "Igor Sikorsky Kyiv Polytechnic Institute", Kyiv, Ukraine

Liubov Panchenko was awarded a Candidate of Pedagogical Sciences degree (Dr. phil.) from $\mathrm{H}$. S. Skovoroda Kharkiv National Pedagogical University, Kharkiv, Ukraine, in 1995, and a Doctor of Pedagogical Sciences degree (Dr. habil.) from the Luhansk Taras Shevchenko National University, in 2012. Since 1993, she has been working in the field of information and communication technology in education. Since 2016 she has been a Professor at the Department of Sociology, National Technical University of Ukraine "Igor Sikorsky Kyiv Polytechnic Institute". Her research interests include information and communication technology in education, university's educational environment, MOOCs, data analysis and multivariate methods in scientific research, digital storytelling, adult education. She has published a number of papers and text books ("Computer data analysis", "Data analysis practicum", "Mathematical and statistical methods of sociological information's analysis") and is an editorial board member of the Ukrainian journals "Information Technologies and Learning Tools" (associated editor), "eEnvironment of Modern University", and "Humanization of the educational process".

WWW: http://www.sociology.kpi.ua/en/faculty-2 e-mail: lubov.felixovna@gmail.com

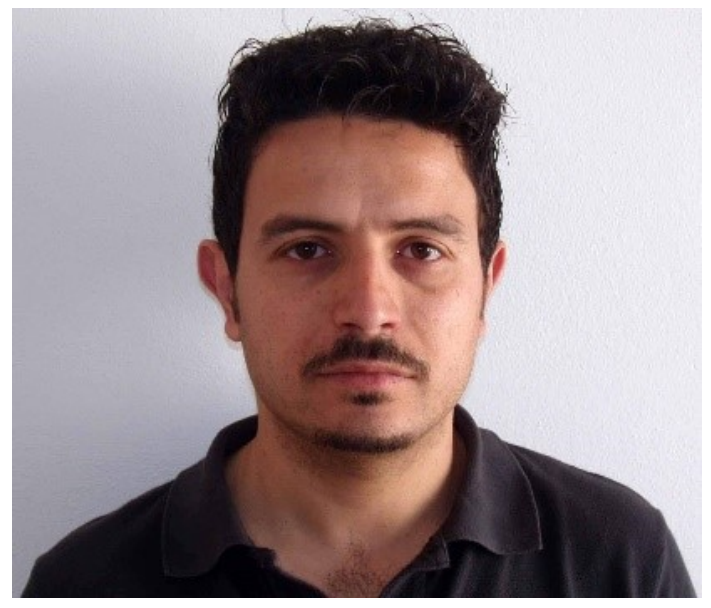

Dr. Stamatios Papadakis, Postdoc researcher, Department of Preschool Education, University of Crete, Greece

Stamatios Papadakis has been a postdoctoral researcher in Educational Technology, with emphasis on mobile learning, at the Department of Preschool Education at the University of Crete, Greece since 2016. He has worked as an adjunct Lecturer in Education teaching Didactics in Programming (2017-2018) at the Department of Computer Sciences, School of Sciences and Engineering at the University of Crete, Greece. Since 2017 he worked as an adjunct Lecturer in Education teaching Informatics (2017-2018) at the Department of Preschool Education, School of Education, University of Crete, Greece. His scientific and research interests include the study of mobile learning, especially on the use of smart mobile devices and their accompanying mobile applications (apps) in the use of Preschool and Primary Education, focusing on the development of Computational Thinking and students' understanding of numbers. Furthermore, he currently investigates how a STEM learning approach influences learning achievement through a context-aware mobile learning environment in the preschool classroom and to explain the effects on preschoolers' learning outcomes.

WWW: https://www.researchgate.net/profile/

Stamatios_Papadakis

e-mail: stpapadakis@uoc.gr

Dr. Oksana Pershukova, Professor of Aviation English Department, National Aviation University, Kyiv, Ukraine 


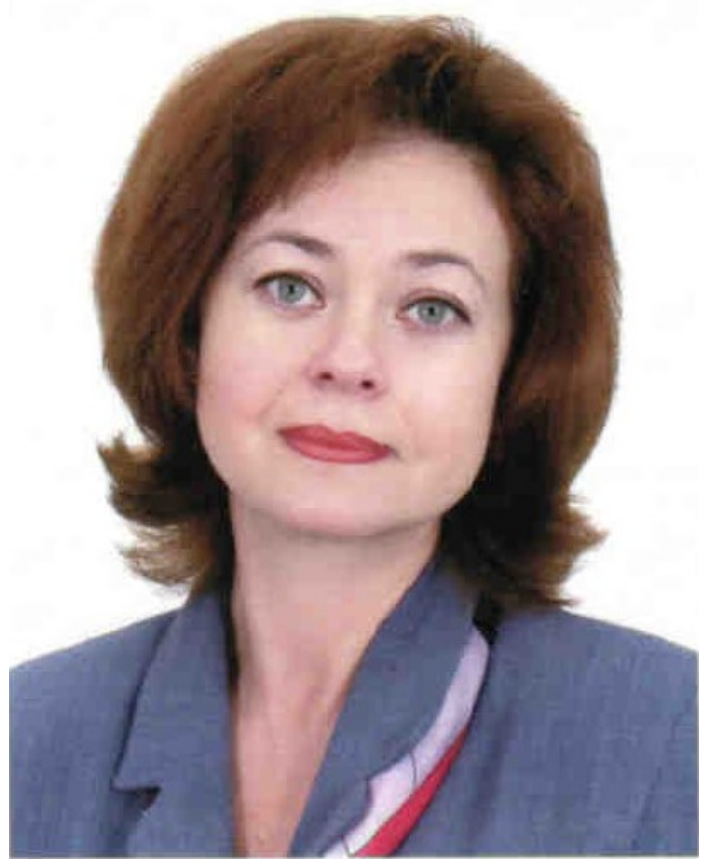

Oksana Pershukova received a Candidate of Pedagogical Sciences degree (Dr. phil.) from the Institute of Pedagogy of the NAPS of Ukraine (Kyiv) in 2002, and a Doctor of Pedagogical Sciences degree (Dr. habil.) from the Institute of Pedagogical Education and Education of Adults of the NAPS of Ukraine (Kyiv), in 2016. Since 1995, she has been working in the field of comparative education in the Institute of Pedagogy, Kyiv. Since 2017 she works at the National Aviation University, Kyiv, at the position of a Professor of Aviation English Department. Her research interests are related to improving the quality of bilingual and multilingual education, developing and preserving multilingualism in the context of the educational space of European countries and the US. She has been analyzing the opportunities and finding ways to apply positive experiences in these fields in Ukraine. The range of her scientific interests also includes features of mastering a foreign language at the university level (especially ESP), as well as peculiarities of forming students' autonomy and finding the ways to increase students' motivation for foreign languages learning.

e-mail: pershoks@gmail.com

Larysa Petrenko, Habilitated doctor, Doctor of Pedagogical Sciences, Department of vocational and higher education of the University of Educational Management, Kyiv, Ukraine

Larysa Petrenko, born in 1951, received a Candidate of Pedagogical Sciences degree (Ph.D.) in 2006 from the Institute of Pedagogy of the National Academy of Educational Sciences of Ukraine, and a Doctor of Pedagogical Sciences from the Institute of Vocational Education of NAESU in 2014. Since 2019, she has been a professor in the field of vocational and higher education at the University of Educational Management. Her research interests include the informational culture, information and an-

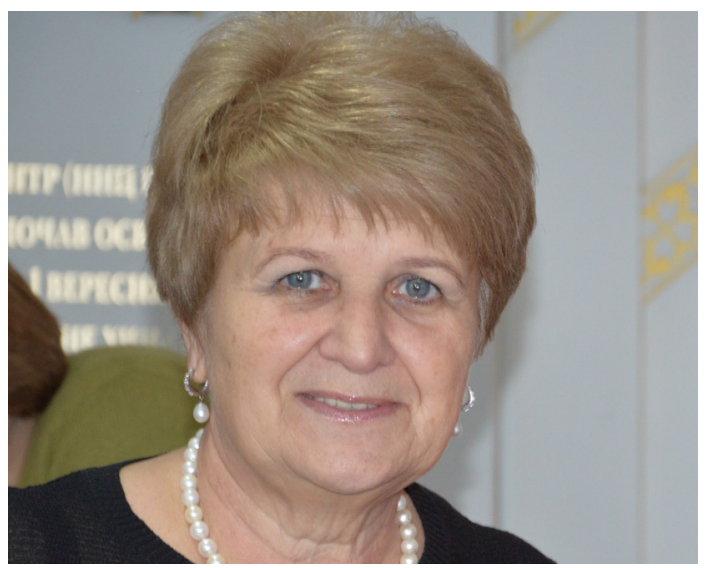

alytical competence of pedagogical, scientific-pedagogical staff and heads of educational institutions of various types. She has published a number of articles in domestic and foreign collections of scientific papers and monographs were published. She is also a member of the editorial board of researcher's digest «Scientific Herald of the Institute of Vocational Education and Training of NAESU. Professional Pedagogy».

WWW: http://umo.edu.ua/institutes/cippo/struktura/ kafedra-upop/sklad

e-mail: laravipmail@gmail.com

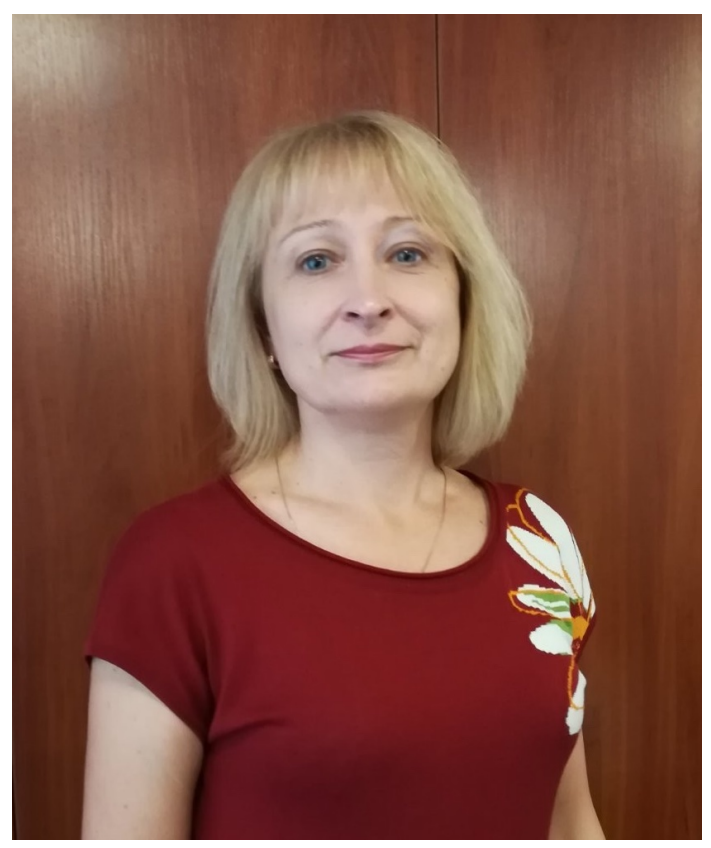

Dr. Olga Pinchuk, Deputy Director for Scientific Experimental Work, Leading Researcher. PhD (in Pedagogics), Senior Researcher in the field of information and communication technologies in education. Education: M.P. Drahomanov Kyiv State Pedagogical Institute in specialties of Mathematics, Computer Science and Computer Engineering teacher.

Currently the experience in teaching is 25 years. Since 2005 I work in the Institute of Information Technologies and Learning Tools of the NAES of Ukraine. I worked on the implementation of the tasks of the scien- 
tific research works "Scientific and methodological foundations use of computer oriented tools in teaching natural and mathematical subjects in profile School", "Scientific and methodological principles of organization of distance learning environment in secondary schools" ," Methodology of design network resource centers of distance education of secondary schools". "Formation of information and educational environment for learning high school students through technology electronic social networks" (Head of Scientific Research), "System of computer modeling of cognitive tasks for the formation of competencies of students in natural and mathematical subjects". I have more than 80 published scientific works, the author of collective monographs, manuals. I also obtain the post of co-editors-in-chief of "Information Technologies and Learning Tools ", a peer-reviewed e-journal in educational sphere, publishing full-text articles online with immediate open-access.

WWW: http://iitlt.gov.ua/

e-mail: opinchuk@iitlt.gov.ua

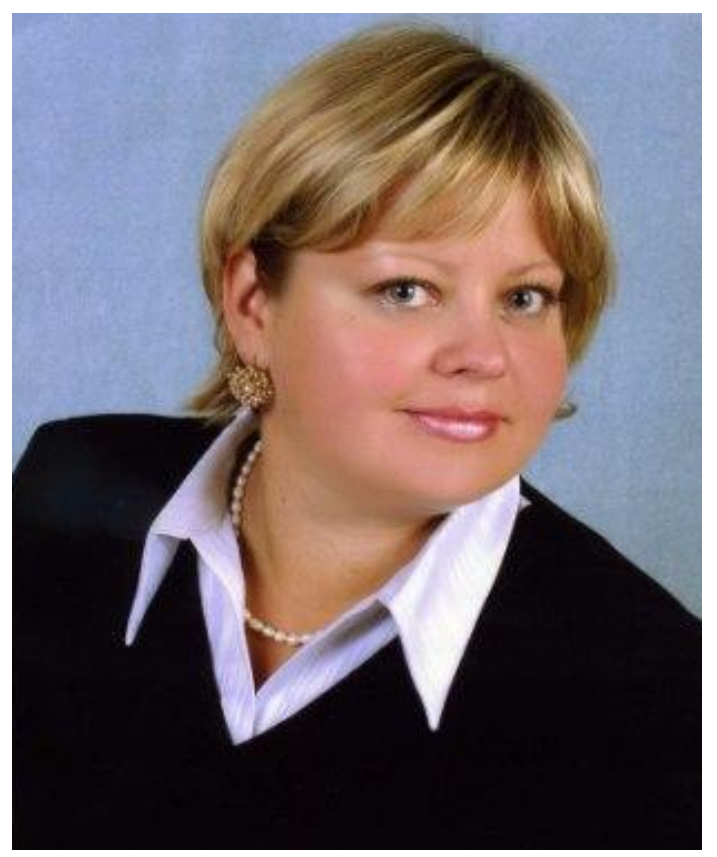

Dr. Nataliia Ponomarova, Professor of Department of Informatics, H. S. Skovoroda Kharkiv National Pedadogical University, Kharkiv, Ukraine

Nataliia O. Ponomarova, born in 1972, received a Candidate of Pedagogical Sciences degree (Dr. phil.) from the H. S. Skovoroda Kharkiv National Pedadogical University, in 1998, and a Doctor of Pedagogical Sciences degree (Dr. habil.) from the H. S. Skovoroda Kharkiv National Pedadogical University, in 2018. Since 2005, she has been working in the field of preparation of teachers of informatics at H. S. Skovoroda Kharkiv National Pedadogical University, where she is currently Dean of Department of Physics and Mathematics. Her research interests include innovative pedagogical technologies; use of information and communication technologies in education; theoretical and methodological foundations of professional training of future teachers of informatics; career guidance of students. She has published a number of papers in international journals and volumes in book series.

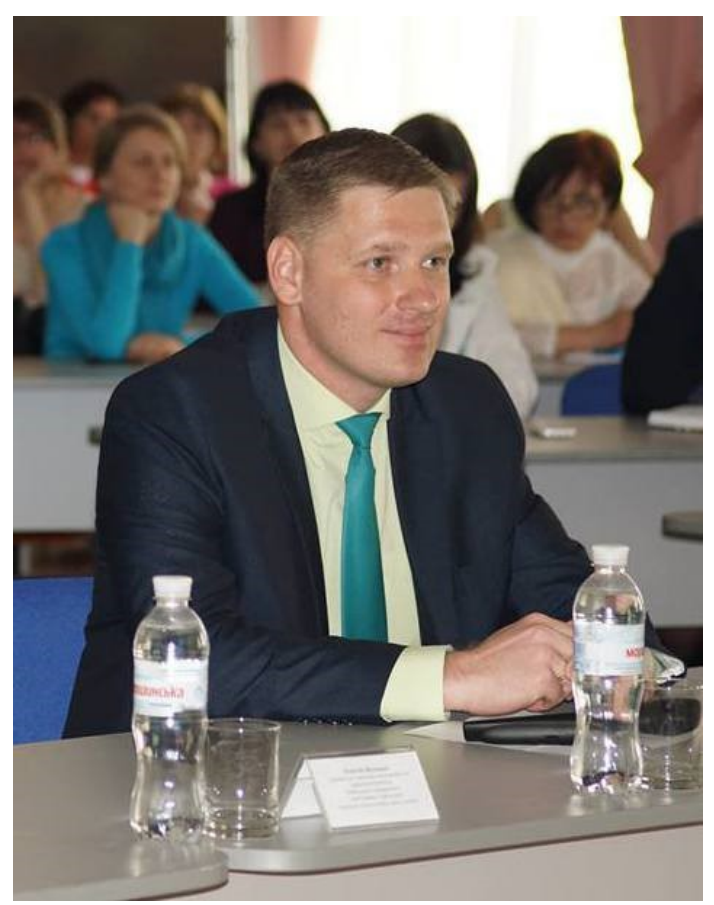

Dr. Volodymyr Proshkin, Professor of Department of Computer Science and Math, Borys Grinchenko Kyiv University, Kyiv, Ukraine

Expert off the National Agency for Higher Education Quality Assurance. Deputy Chairman of the Specialized Academic Council (Borys Grinchenko Kyiv University), member of the specialized Academic Council (Donbass State Pedagogical University). Executor of the international project «High school teacher competence in change» with the assistance of the Visegrad Fund and the Ministry of Foreign Affairs of the Netherlands. Author of 10 articles in journals included in the databases Scopus, WOS. Member of editorial boards of journals: «Open educational e-environment of modern University», «Cybersecurity: Education, Science, Technique» (Borys Grinchenko Kyiv University), «Transactions of Kremenchuk Mykhailo Ostrohradskyi National University».

WWW: http://fitu.kubg.edu.ua/pro-fakultet/kafedry

e-mail: v.proshkin@kubg.edu.ua

Dr. Oleg Pursky, Professor of Computer Science and Information Systems, Head of Department of Computer Science and Information Systems, Kyiv National University of Trade and Economics, Kyiv, Ukraine

Oleg Pursky, born in 1967, received a Candidate of Sciences in Physics and Mathematics degree (Dr. phil.) from the Institute for Low Temperature Physics and Engineering of the National Academy of Sciences of Ukraine, in 2001, and a Doctor of Sciences in Physics and Mathematics degree (Dr. habil.) from the Taras Shevchenko National University of Kyiv, Ukraine, in 2010. His research interests include informational systems development, computer simulation and modeling of socio- 


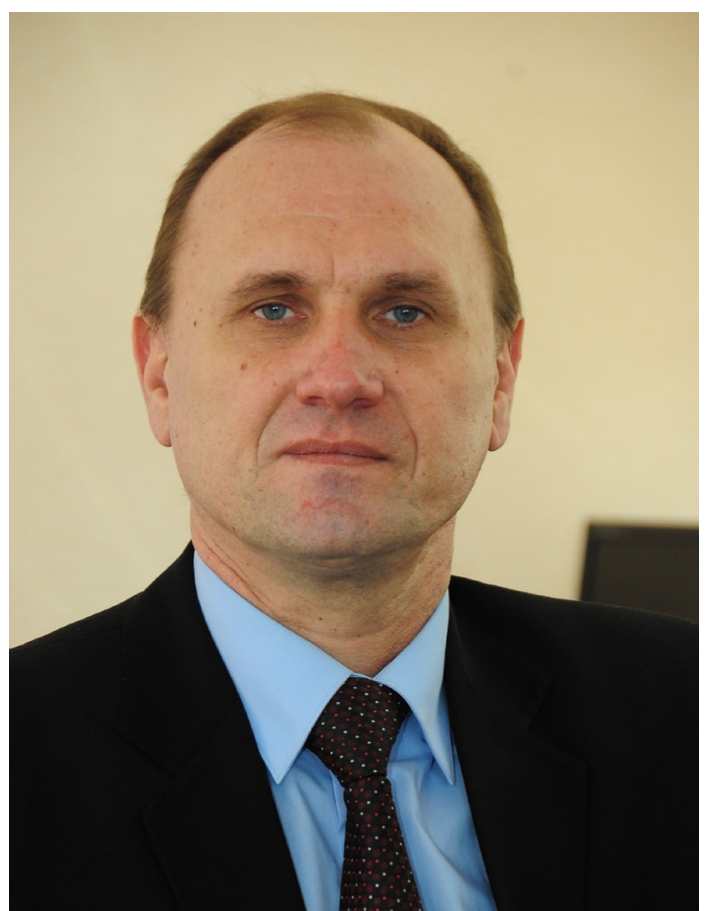

economic systems. He has published a number of papers in international journals, monographs and volumes in book series, is a member of editorial board of International Journal of Economic Theory and Application, reviewer of scientific journals International Journal of Modern Physics (B) and Heat Transfer and certified Data Science\&Machine Learning specialist. He is a member of Scientific Council section of Ukrainian Ministry of Education and Science on the specialty "Informatics and Cybernetics". Currently, he is working as a Head of Department of Computer Science and Information Systems, Kyiv National University of Trade and Economics. uk

WWW: https://knute.edu.ua/blog/read/?pid=12695\&

$$
\text { e-mail: Pursky_O@ukr.net }
$$

Dr. Serhiy Semerikov, Professor of Computer Science and Educational technology, Kryvyi Rih State Pedagogical University, Ukraine

Serhiy Semerikov is professor of Department of Computer Science and Applied Mathematics at Kryvyi Rih State Pedagogical University. He got both $\mathrm{PhD}$ and DSc in education (informatics) from the National Pedagogical Dragomanov University in 2001 and 2009, respectively. The main directions of Dr. Semerikov' research is methods of learning and educational technology.

WWW: https://kdpu.edu.ua/semerikov/ e-mail: semerikov@gmail.com

Dr. Yevhenii Shapovalov, Chief specialist in Ministry of Digital Transformation of Ukraine and Researcher in National Center "Junior Academy of Science of Ukraine"

Yevhenii Shapovalov was born in 1992, received Ph.D. in 2020 from the National University of Life and Environmental Sciences of Ukraine in biotechnology. He worked in the field of digitalization of chemistry education in the
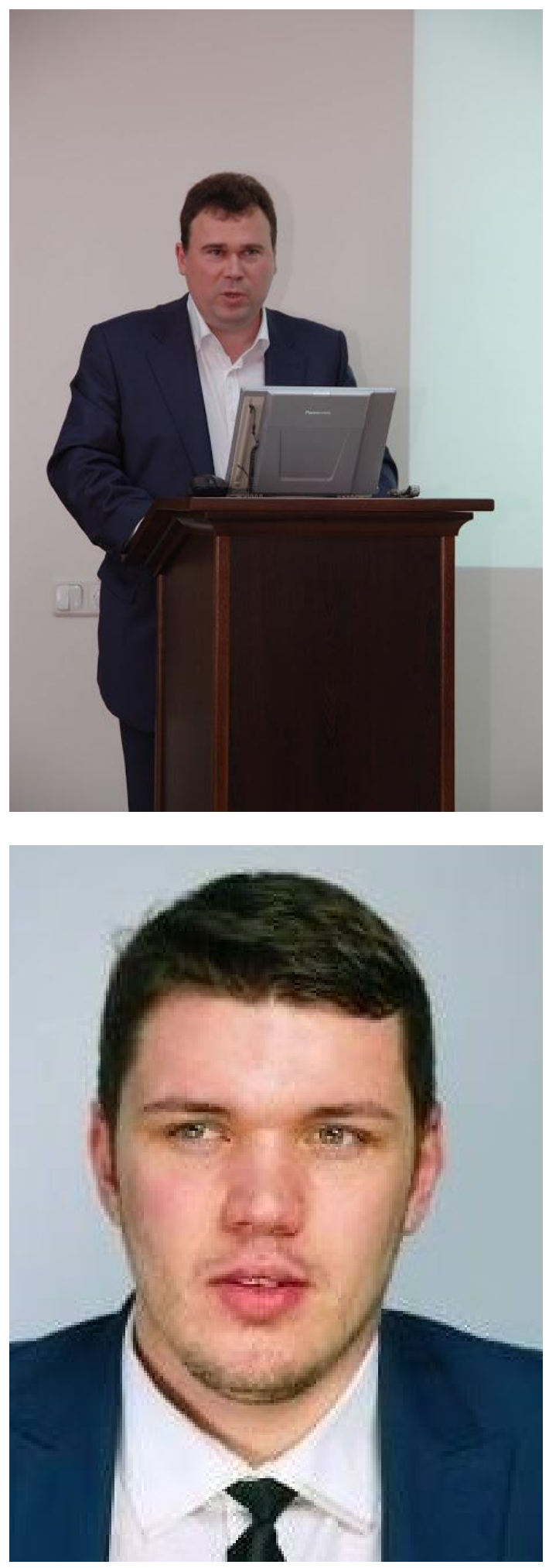

National Center "Junior Academy of Science of Ukraine" from 2014 to 2020 and then start to work in the Ministry of Digital transformation. He has studied the anaerobic digestion of high nitrogen content in biotechnology and modern approaches in the digitalization of education, such as using AR, smart tools, and ontologies to structure education content. He is a board member of NGO "European Studies' Platform for Sustainable Development" and has experience in international educational projects (Erasmus+). 
WWW: http://www.nas.gov.ua/UA/PersonalSite/ Pages/default.aspx?PersonID=0000026333

e-mail: sjb@man.gov.ua,shapovalov@thedigital.gov. ua

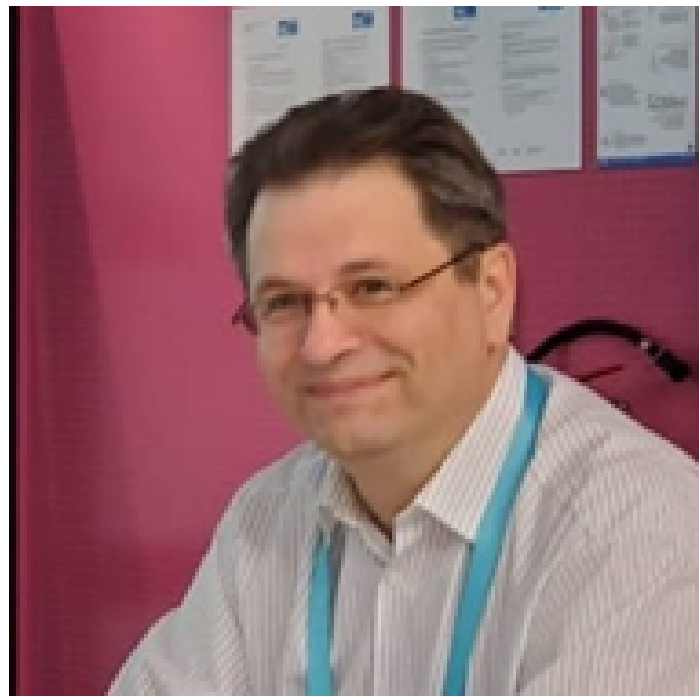

Dr. Yaroslav Shramko, Professor of Logic and Philosophy, Department of Philosophy, Kryvyi Rih State Pedagogical University, Kryvyi Rih, Ukraine

Yaroslav Shramko, born in 1963, received a Candidate of Philosophical Sciences degree (Dr. phil.) from the Lomonosov Moscow State University, USSR, in 1990, and a Doctor of Philosophical Sciences degree (Dr. habil.) from the Institute of Philosophy of the National Academy of Sciences of Ukraine, in 1998. Since 1990, he has been working in the field of logic and analytic philosophy at the Kryvyi Rih State Pedagogical University, where he is currently rector. His research interests include non-classical logic and analytic philosophy. He has published a number of papers in international journals and volumes in book series, is a member of editorial boards of Studia Logica, European Journal of Mathematics, Logic and Logical Philosophy.

WWW: https://kdpu.edu.ua/shramko/yse.htm e-mail: shramko@rocketmail.com

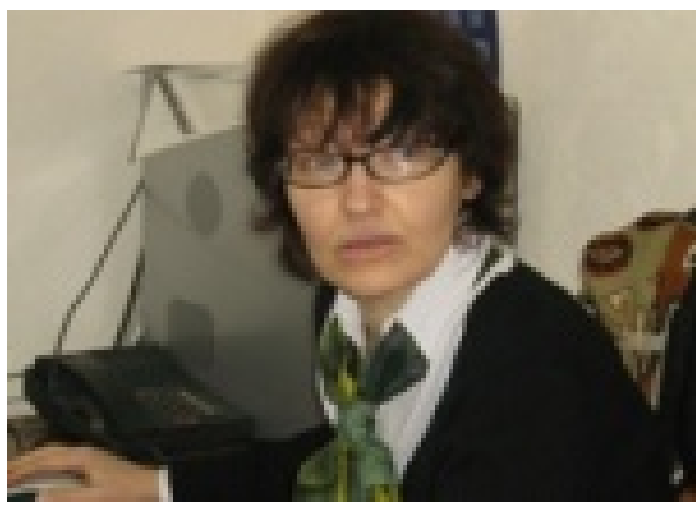

Dr. phil. Oleksandra Sokolyuk, Acting Deputy of Scientific Secretary Institute of Information Technologies and Learning Tools of NAES of Ukraine, Kyiv, Ukraine
Oleksandra Sokolyuk, born in 1962, received a Candidate of Pedagogical Sciences degree (Dr. phil.) from the National Pedagogical University named after M. Drahomanov, Kyiv, Ukraine. Senior Researcher in specialty 13.00.10 - information and communication technologies in education (2014). His research interests include IKT in education, educational research, is a member of editorial boards of "Information Technologies and Learning Tools".

WWW: http://iitlt.gov.ua/eng/structure/

e-mail: sokolyuk62@gmail.com

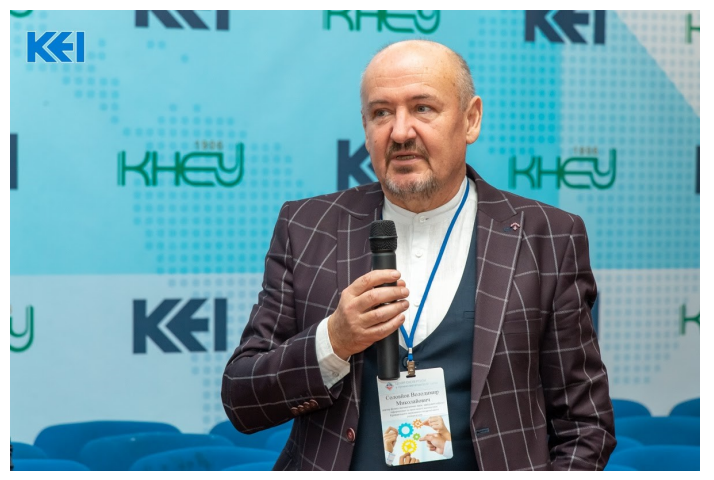

Vladimir N. Soloviev received the D. Sc. (Dr. Hab.) degree in solid state physics from Institute of Physics of the National Academy of Sciences of Ukraine, in 1993. From 1992 to 2000 and from 2016 to the present head of the Department of Informatics and Applied Mathematics of Kryvyi Rih State Pedagogical University. In the period from 2000 to 2016, he carry out research on critical and crisis phenomena in the financial markets at various universities in Kyiv, Cherkassy and Kryvyi Rih. He has about 300 publications in the field of solid state physics, complex systems and quantitative methods of constructing precursors of crisis phenomena in systems of different nature.

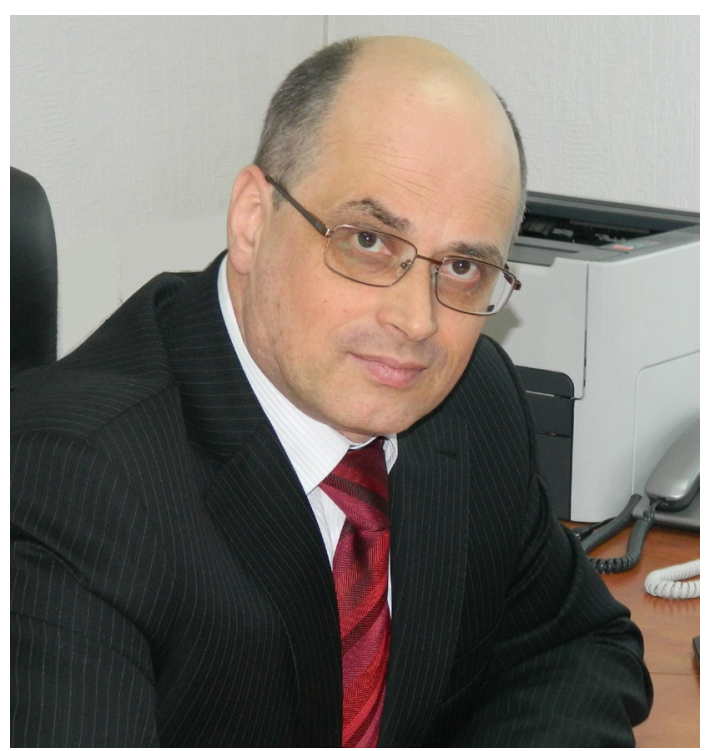

Oleg Spirin, Doctor of Pedagogy, Full Professor, Corresponding Member of the National Academy of Pedagog- 
ical Science of Ukraine, Vice Rector for Research and Digitalization of the University of Educational Management, Kyiv, Ukraine

Oleg Spirin, born in 1965, 1989 - graduated from Zhytomyr Ivan Franko State University, Ukraine, majoring in Mathematics and Physics. Scientific degree: Ph.D (2002), Thesis "Differentiated approach to the Study of the Foundations of Artificial Intelligence in Computer Science Course Physics and Mathematics in Higher Educational Institutions"; Doctor of Pedagogical Sciences (2009), Thesis "Theoretical and Methodological Basis of Credit-modular System of Future Teachers of Informatics Training". Academic status: Associate Professor of Computer Science (2004) Professor of the specialty 13.00.10 - Information Technologies in Education (2013). Prof. Spirin is an expert in the informatization of education and science and information training of students. He has published a number of papers in international journals and volumes in book series, is Deputy Editor-in-Chief of Electronic scientific edition "Information Technologies and Learning Tools", member of the Editorial Boards of the specialized journals "Information Technologies in Education", "Computer in School and Family".

WWW: http://umo.edu.ua/en/university/leadership/ spirin-olegh-mikhajlovich

e-mail: oleg.spirin@gmail.com

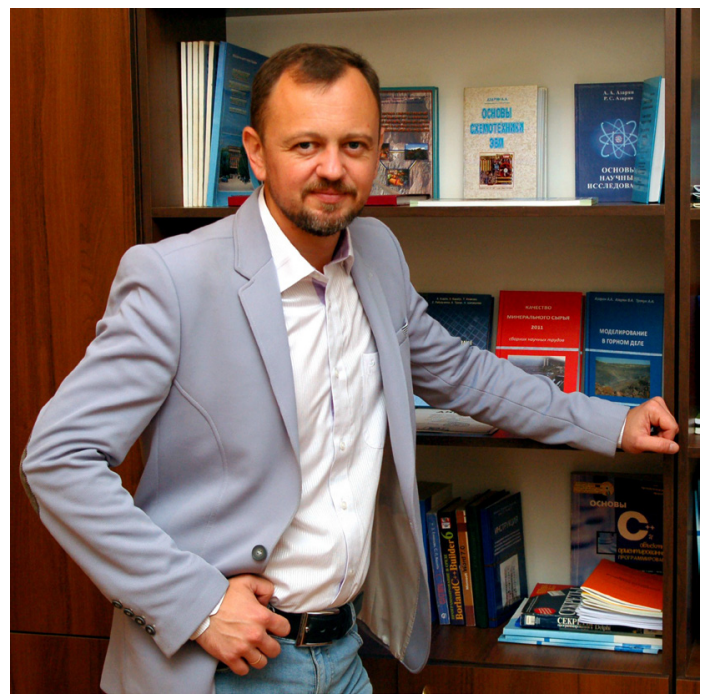

Dr. Andrii Striuk, Ph.D., Head of Simulation and Software Engineering department of Kryvyi Rih National University, Kryvyi Rih, Ukraine

Andrii Striuk, born in 1979. In 2000 he graduated from the Kryvyi Rih Technical University with a degree in Automated Systems Software. In 2001, he received a master's degree in computer science. Has been working at the Department of Modeling and Software of Kryvyi Rih National University since 2000. Combines educational activities with practical, developing and implementing educational software products. In 2011 he defended his Ph.D. thesis. From 2014 to 2017 he is studying at the doctoral program in Institute of Information Technologies and Learning Tools of the NAES of Ukraine (Kyiv,
Ukraine). In 2017, he was awarded the Prize of the President of Ukraine for young scientists. Heads the Simulation and Software Engineering department of Kryvyi Rih National University since 2018. Field of scientific interest: professional training of software engineers, mobile learning technologies, the use of augmented reality technologies in education.

WWW: http://mpz.knu.edu.ua/pro-kafedru/ vikladachi/224-andrii-striuk

e-mail: andrii.striuk@knu.edu.ua

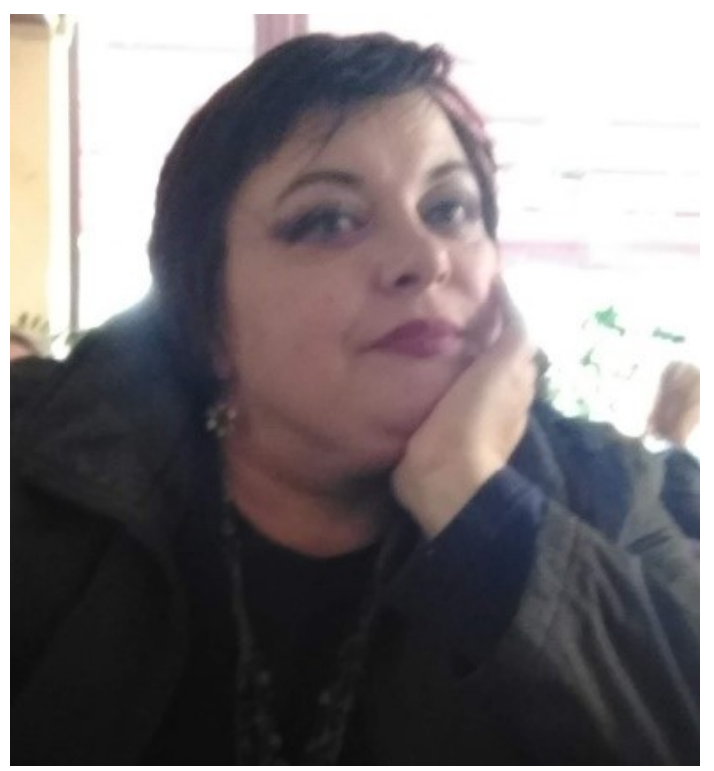

Dr. Iryna Mykolaivna Trubavina - Doctor of Pedagogical science, Professor of the Department of Social and Humanitarian Disciplines of the National Academy of the National Guard of Ukraine, of the Department of General pedagogics and pedagogic of High education, H. S. Skovoroda Kharkiv National Pedagogical University, consultant of the La Strada-Ukraina (2000-2015), scientific consultant of the State Social services for families, children and youth (2000-2006). Field of scientific interest: social pedagogics, social work, education, family, pedagogic's skills. She is Editor of the journal "Social Work in Ukraine: Theory and Practice", «Społeczna Pedagogika». WWW:

trubavina-iryna-mykolayivna http://hnpu.edu.ua/uk/

e-mail: trubavina@gmail.com

Dr. Tetiana Vakaliuk, professor, professor of the department of Software Engineering, Zhytomyr Polytechnic State University, Zhytomyr, Ukraine.

Tetiana Vakaliuk, born in 1983, received a Candidate of Pedagogical Sciences degree from the National Pedagogical Dragomanov University, Ukraine, in 2013, and a Doctor of Pedagogical Sciences degree from the Institute of Information Technologies and Learning Tools of the National Academy of Sciences of Ukraine, in 2019. Since 2019, she has been working in the field of information technologies at the Zhytomyr Polytechnic State University. Her research interests include information technologies, ICT in Education, Cloud technologies. She has 


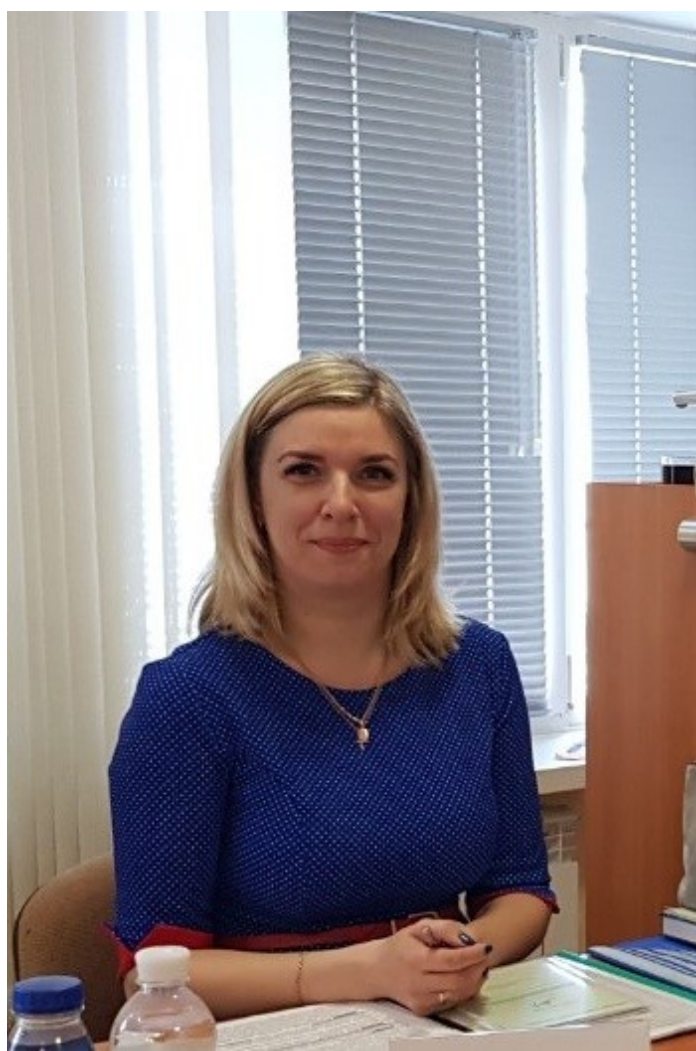

published a number of papers in international journals, is a member of editorial boards of Information Technologies and Learning Tools, Zhytomyr Ivan Franko State University Journal: Pedagogical Sciences, Collection of Scientific Papers of Uman State Pedagogical University.

WWW: https://sites.google.com/view/neota e-mail: tetianavakaliuk@gmail.com

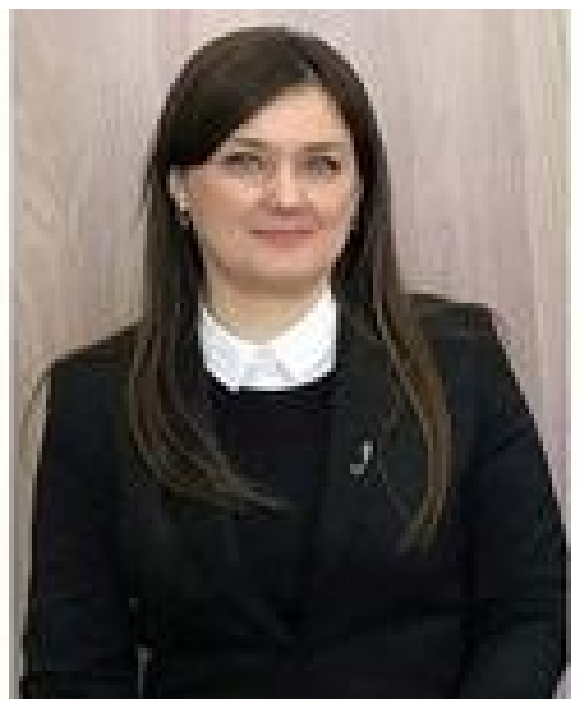

Dr. Maryna Vardanian, Full Professor of Children's Literature and Comparative Literature, Faculty of Foreign Languages, Kryvyi Rih State Pedagogical University, Kryvyi Rih, Ukraine

Maryna Vardanian, born in 1979, received a Candidate of Philological Sciences degree (PhD in Philology) from The Volodymyr Vynnychenko State Pedagogical Univer- sity of Kirovograd (Kropyvnytskyi, Ukraine), in 2010, and a Doctor of Philological Sciences degree (Dr. habil.) from The Bohdan Khmelnytsky National University of Cherkasy, Ukraine, in 2019. Since 2012, she has been working in the field of children's literature and comparative literature at The Kryvyi Rih State Pedagogical University, where she is currently Dean of Faculty of Foreign Languages. Her research interests include literary imagology, translating studies and literature written by Ukrainian Diaspora. She has published a number of papers in journals, is a member of International Research Society for Children's Literature, and editorial board of Literatures of the World: Poetics, Mentality and Spirituality.

WWW: https://kdpu.edu.ua/personal/pm_rectora.html e-mail: maryna.vardanian@gmail.com

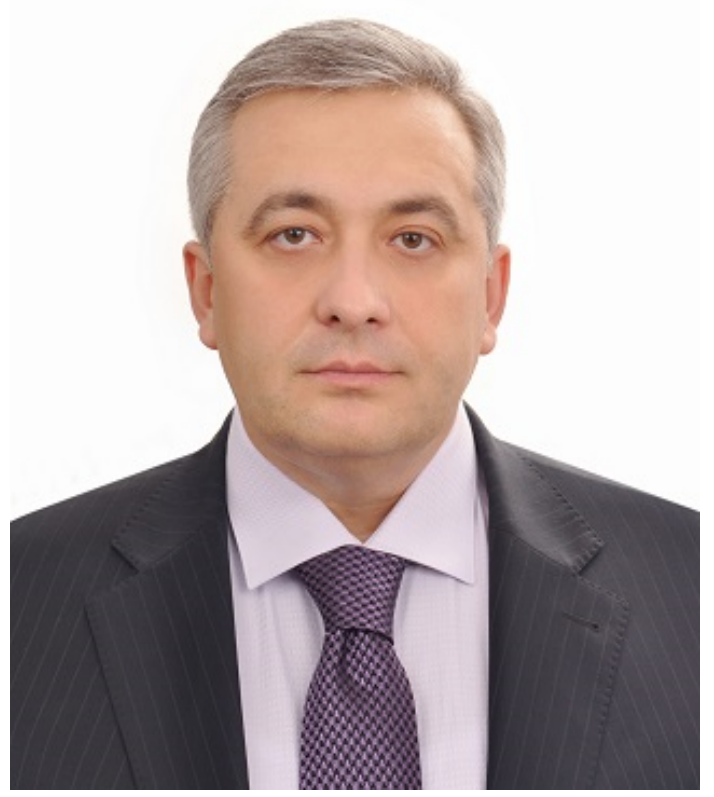

Dr. Vladyslav Velychko, Associate Professor of Methods of Teaching Mathematics and Methods of Teaching Computer Science, Faculty of Physics and Mathematics, Donbas State Pedagogical University, Sloviansk, Ukraine

Vladyslav Velychko, born in 1973, received a Candidate of Physical and Mathematical Sciences degree (Dr. phil.) from the Kyiv Taras Shevchenko National University, Ukraine, in 2006, and a Doctor of Pedagogical Sciences degree (Dr. habil.) from the Donbas State Pedagogical University, in 2019. Since 1994, he works in the field of algebra, methods of teaching computer science, the use of information and communication technologies in education at Donbas State Pedagogical University, where he is now head of the department. Research interests - quasiideals of semigroups, algorithms on algebraic structures, free software, open electronic educational resources. He has published a number of articles in international journals and made presentations at international conferences and seminars.

WWW: https://ddpu.edu.ua/cc/velychko 
e-mail: vladislavvelichko@gmail.com

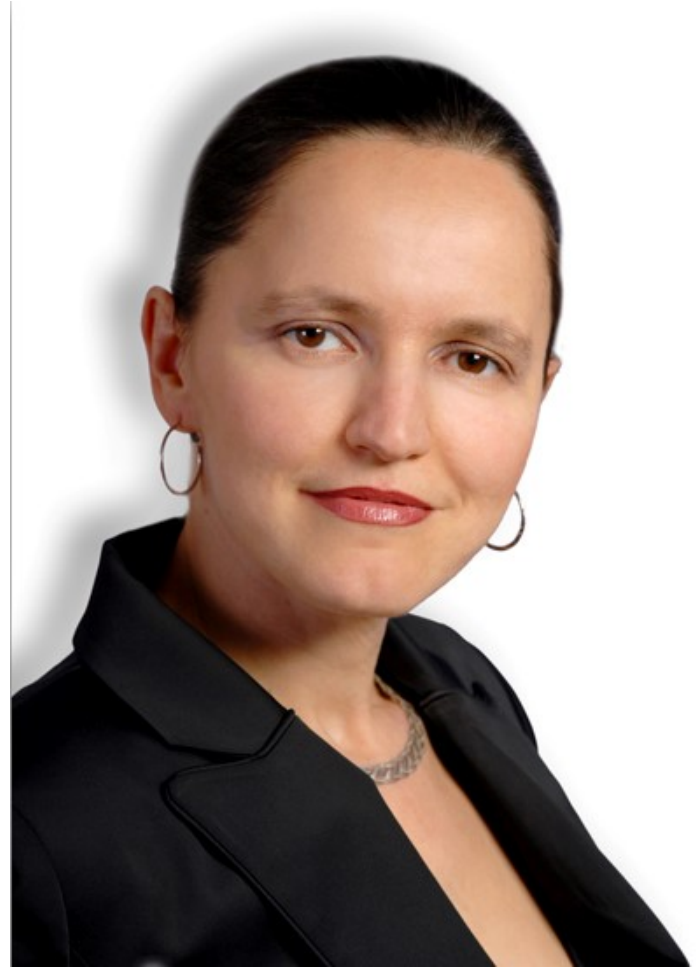

Dr. Kateryna Vlasenko, Professor of Maths, Department of Mathematics and Modeling, Donbas State Engineering Academy, Kramatorsk, Ukraine

Kateryna Vlasenko, born in 1966, received a Candidate of Pedagogical Sciences degree (PhD) from the National Pedagogical Dragomanov University, Ukraine, in 2004, and a Doctor of Pedagogical Sciences degree (D.Sc. in Educational Science) from the Bohdan Khmelnytsky National University of Cherkasy, in 2011. Since 2008, she has been working in the field of mathematical and pedagogical modeling at Donbas State Engineering Academy. Her research interests include the issues of mathematics education. She has published a number of papers in international journals and volumes in book series, is a member of editorial boards of Innovative Solutions in Modern Science, Topical Issues of Natural and Mathematical Education Sumy State Pedagogical University named after A. Makarenko.

WWW: http://formathematics.com/tutors/ kateryna-vlasenko/

e-mail:vlasenkokv@ukr.net

Nataliia P. Volkova, Doctor of Pedagogy, Professor, Head of the Department of Innovative Technologies in Pedagogy, Psychology and Social Work, Alfred Nobel University, Dnipro, Ukraine

Leading expert in pedagogy of higher education in Ukraine. Chairperson of Specialized Academic Board on PhD dissertations in "Theory and Methodology of Professional Education". Author of more than 170 printed works, three monographs, two textbooks with a stamp of the Ministry of Education and Science of Ukraine, three study guides with a stamp of the Ministry of Education

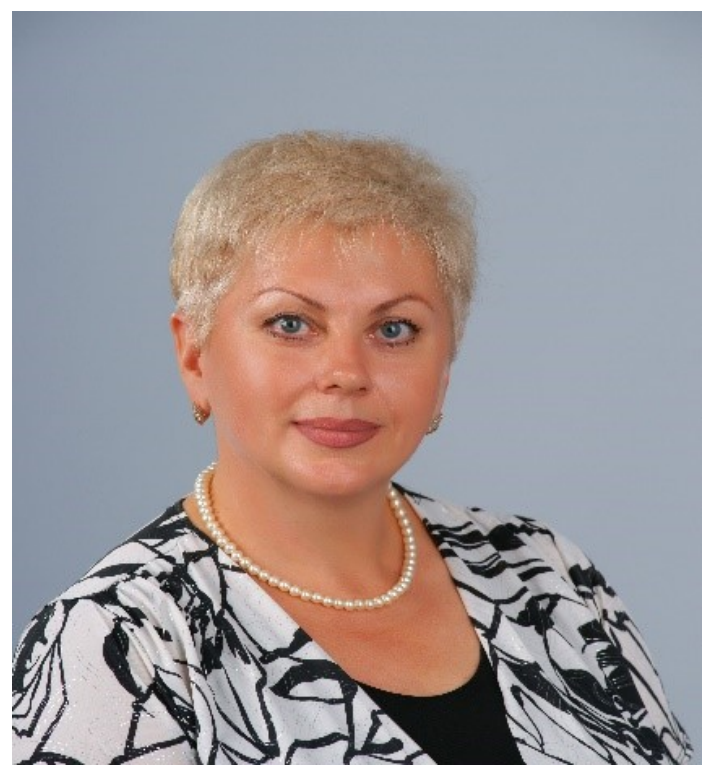

and Science of Ukraine, 12 educational and practical study guides, articles in leading Ukrainian and foreign journals. Author of "Pedagogy", "Professional-Pedagogic Communication" - the textbooks now fundamental in many leading institutions of higher education in Ukraine.

WWW: https://duan.edu.ua/university-ukr/kafedry/ 15-pages/332-kafedra-pedahohiky-ta-psykholohii.html e-mail: npvolkova@yahoo.com

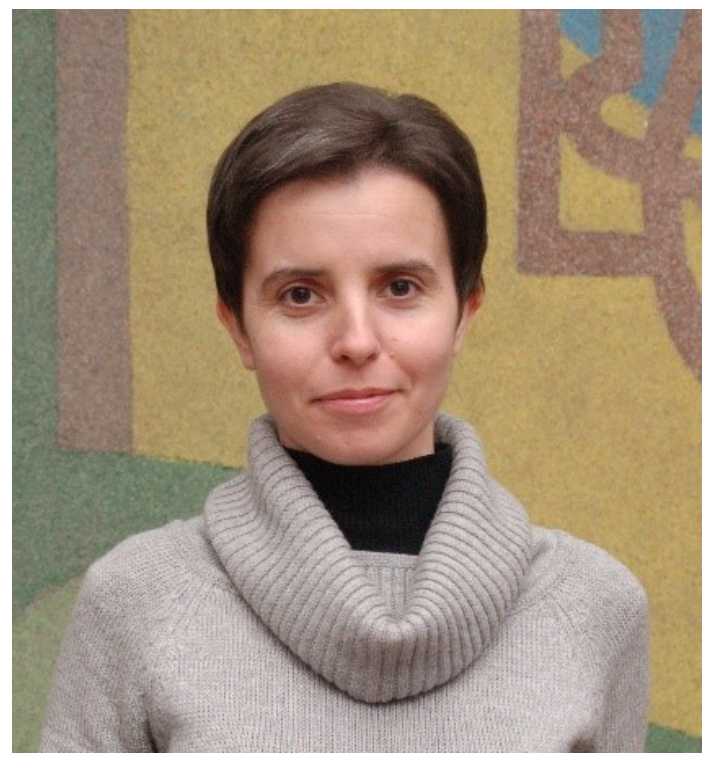

Dr. Yuliia Yechkalo, Associate professor, Department of Physics, Kryvyi Rih National University, Kryvyi Rih, Ukraine

Yuliia Yechkalo, born in 1981, received a Candidate of Pedagogical Sciences degree from the Kirovograd State Vladimira Vinnichenka Pedagogical University, Ukraine, in 2013. Since 2005, she has been working at the National Metallurgical Academy of Ukraine. She has been working at the Kryvyi Rih National University since 2012. Her research interests include theory and methods of education 
(physics) and information and communication technologies in education.

e-mail: uliaechk@gmail.com

\section{ICHTML 2021: Conclusion and outlook}

The vision of the ICHTML 2021 is to create a leading interdisciplinary platform for researchers, practitioners and educators, to present and discuss the most recent innovations, trends, and concerns as well as practical challenges encountered and solutions adopted in the fields of learning.

The conference is a successfully performing forum to transferring and discussing research result among the academics, students, teachers, government, private sector or industries. Participants and presenters from several countries such as Czechia, Finland, Netherlands, Poland, Russia, Slovakia and Ukraine have attended the conference to share their significant contribution in research related to the History, Theory and Methodology of Learning.

We are thankful to all the authors who submitted papers and the delegates for their participation and their interest in ICHTML as a platform to share their ideas and innovation. Also, we are also thankful to all the program committee members for providing continuous guidance and efforts taken by peer reviewers contributed to improve the quality of papers provided constructive critical comments, improvements and corrections to the authors are gratefully appreciated for their contribution to the success of the conference. Moreover, we would like to thank the developers and other professional staff of Not So Easy Science Education platform (https://notso. easyscience.education), who made it possible for us to use the resources of this excellent and comprehensive conference management system, from the call of papers and inviting reviewers, to handling paper submissions, communicating with the authors etc.

We are looking forward to excellent presentations and fruitful discussions, which will broaden our professional horizons. We hope all participants enjoy this conference and meet again in more friendly, hilarious, and happiness of further ICHTML 2022.

\section{References}

[1] V. Hamaniuk, S. Semerikov, Y. Shramko, SHS Web of Conferences 75, 00001 (2020)

[2] N. Dichek, SHS Web of Conferences p. 01002 (2021, in press)

[3] I. Trubavina, L. Petryshyn, A.M. Cwer, J. Polacko, G. Monastyrskyi, V. Kultchyckyi, O. Mirshuk, Y. Medvid, SHS Web of Conferences p. 01006 (2021, in press)

[4] S. Alieksieieva, L. Yershova, S. Kravets, O. Lapshyna, H. Odnoroh, SHS Web of Conferences p. 03002 (2021, in press)

[5] G. Tereshchuk, H. Meshko, M. Prochazka, O. Meshko, H. Radchuk, SHS Web of Conferences p. 01003 (2021, in press)
[6] O. Kravchenko, I. Albul, SHS Web of Conferences p. 01001 (2021, in press)

[7] O. Lokshyna, A. Dzhurylo, O. Hlushko, O. Shparyk, SHS Web of Conferences p. 01004 (2021, in press)

[8] G. Lyubenov, O. Zyma, H. Brusiltseva, N. Dekhtyar, N. Pohuda, SHS Web of Conferences p. 01005 (2021, in press)

[9] T. Derkach, A. Kolodyazhna, Y. Shuhailo, SHS Web of Conferences p. 02001 (2021, in press)

[10] O. Chebykin, O. Kosyanova, A. Vinkovska, SHS Web of Conferences p. 02004 (2021, in press)

[11] I. Batsurovska, N. Dotsenko, O. Gorbenko, N. Kim, SHS Web of Conferences p. 02014 (2021, in press)

[12] L. Sultanova, L. Khomych, O. Tsiuniak, O. Romaniuk, SHS Web of Conferences p. 02013 (2021, in press)

[13] V. Shpak, A. Klim-Klimashevska, T. Ninova, SHS Web of Conferences p. 02010 (2021, in press)

[14] O. Pavlyk, L. Lysohor, J. Lampiselka, SHS Web of Conferences p. 02011 (2021, in press)

[15] L.I. Bilousova, L.E. Gryzun, N.V. Zhytienova, SHS Web of Conferences p. 02015 (2021, in press)

[16] M.B. Yevtuch, V.M. Fedorets, O.V. Klochko, N.P. Kravets, T.R. Branitska, SHS Web of Conferences p. 02008 (2021, in press)

[17] N. Valko, V. Osadchyi, SHS Web of Conferences p. 02016 (2021, in press)

[18] O. Petryshyna, M. Boyko, SHS Web of Conferences p. 02012 (2021, in press)

[19] N. Ponomarova, O. Gulich, O. Zhernovnykova, N. Olefirenko, V. Masych, SHS Web of Conferences p. 02017 (2021, in press)

[20] O. Polishchuk, N. Kovtun, I. Vitiuk, R. Sapeńko, B. Trocha, SHS Web of Conferences p. 02007 (2021, in press)

[21] Y. Kodliuk, N. Bibik, I. Kodliuk, L. Kodliuk, O. Radchenko, SHS Web of Conferences p. 02009 (2021, in press)

[22] O. Olifer, SHS Web of Conferences p. 02005 (2021, in press)

[23] V.M. Fedorets, M.B. Yevtuch, O.V. Klochko, N.P. Kravets, R.S. Grynyov, SHS Web of Conferences p. 02006 (2021, in press)

[24] N. Sivrikova, T. Ptashko, S. Roslyakova, N. Sokolova, R. Dimuhametov, SHS Web of Conferences p. 02002 (2021, in press)

[25] L. Lokhvytska, N. Martovytska, SHS Web of Conferences p. 02003 (2021, in press)

[26] O. Yankovych, I. Kuzma, V. Prymakova, Z. Onyshkiv, H. Chaikovska, SHS Web of Conferences p. 03004 (2021, in press)

[27] N. Volkova, O. Lebid, L. Verchenko, N. Bidnenko, V. Zirka, SHS Web of Conferences p. 03011 (2021, in press)

[28] V. Kovalchuk, T. Aheikina-Starchenko, N. Chorna, S. Iskra, SHS Web of Conferences p. 03012 (2021, in press) 
[29] N. Slukhai, L. Slavova, S. Slukhai, M. Omelianchuk, SHS Web of Conferences p. 03005 (2021, in press)

[30] N. Volkova, O. Lebid, O. Hrom, N. Zinukova, T. Korobeinikova, SHS Web of Conferences p. 03003 (2021, in press)

[31] S. Symonenko, N. Zaitseva, V. Osadchyi, SHS Web of Conferences p. 03007 (2021, in press)

[32] H. Ihnatenko, I. Marynchenko, O. Ihnatenko, E. Marynchenko, A. Zinchenko, SHS Web of Conferences p. 03013 (2021, in press)

[33] V. Steshenko, V. Velychko, S. Yashanov, N. Vovk, O. Kitova, SHS Web of Conferences p. 03015 (2021, in press)

[34] O. Glazunova, T. Saiapina, V. Korolchuk, O. Kasatkina, T. Voloshyna, SHS Web of Conferences p. 03001 (2021, in press)
[35] O. Pershukova, O. Matviyenko, O. Vasiukovych, N. Nikolska, SHS Web of Conferences p. 03006 (2021, in press)

[36] T. Vakaliuk, I. Novitska, I. Verbovsky, T. Rozhnova, V. Kontsedailo, SHS Web of Conferences p. 03008 (2021, in press)

[37] V. Moshinski, N. Pozniakovska, O. Mikluha, M. Voitko, SHS Web of Conferences p. 03009 (2021, in press)

[38] I. Trubavina, O. Karaman, D. Kamenova, V. Stepanenko, Y. Yurkiv, SHS Web of Conferences p. 03010 (2021, in press)

[39] M. Medvid, N. Trobyuk, M. Storoska, O. Lysychkina, Y. Medvid, SHS Web of Conferences p. 03014 (2021, in press) 